\title{
Human Spinal Cord Neurons in Dissociated Monolayer Cultures: Morphological, Biochemical, and Electrophysiological Properties ${ }^{1}$
}

\author{
A. C. KATO, ${ }^{2}$ G. TOUZEAU, D. BERTRAND,* aND C. R. BADER* \\ Department of Pharmacology and *Department of Physiology, Centre Médical Universitaire, 9 avenue de Champel, 1211 Geneva 4 , \\ Switzerland
}

\begin{abstract}
The preparation of dissociated monolayer cultures from embryonic human spinal cord is described. Optimal survival was achieved with embyronic tissue between the eighth and ninth week. The neurons survive for as long as 7 weeks in culture and they grow in a standard tissue culture medium which contains $13 \%$ decomplemented human serum. The neurons have been identified by indirect immunofluorescence techniques using antibodies to tetanus toxin and neurofilament protein. Our biochemical studies demonstrate the presence of cholinergic and GABAergic neurons. Cholinergic neurons develop in culture and are more numerous in the cultures prepared from the anterior part of the spinal cord as compared to those from the posterior part. Therefore, it is possible that a large part of the cholinergic neurons derive from the motoneuron pool. Electrical membrane properties were studied with patch electrodes using the whole cell recording technique. Neurons had short duration action potentials that could be blocked by tetrodotoxin (TTX). Voltage clamp experiments combined with the use of pharmacological blocking agents revealed the presence of several voltageand time-dependent currents: (1) a sodium current sensitive to $\pi \mathrm{X},(2)$ a potassium current made up of two components, sensitive to tetraethylammonium and 4-aminopyridine, and (3) a calcium current sensitive to cobalt. From a biochemical and electrophysiological point of view the properties of human spinal cord neurons in culture closely resemble the properties of spinal cord neurons from other species.
\end{abstract}

The study of neurological diseases affecting the human spinal cord is complicated by the inability to do experiments directly on

Received February 8, 1985;

Accepted March 8, 1985

${ }^{1}$ We are most grateful for the assistance of Dr. J. Cox (Department of Pathology, University of Geneva) who was instrumental in the initiation of this work and to the members of the Department of Gynecology and Obstetrics, Geneva Cantonal Hospital, particularly, Professor $\Gamma$. Krauer and Ms. L. Popovic. We would also like to express our gratitude to the members of the Transfusion Center, Geneva Cantonal Hospital, who regularly supplied us with fresh human blood. We thank Y. Dunant, N. Spitzer, and M. Weber for their helpful criticisms and F. Steimer and F. Pillonel for their excellent technical assistance.

This work was supported by grants from the Amyotrophic Lateral Sclerosis Society of America, the Muscular Dystrophy Association (U. S. A.), the Fondation de Reuter (Geneva), and the Swiss National Science Foundation (Grant 3.230.0.82 to A. C. K. and Grant 3.210.0.82 to C. R. B. and D. B.).

${ }^{2}$ To whom correspondence should be addressed, at Department of Pharmacology, Centre Médical Universitaire, 9 avenue Champel, $1211 \mathrm{Ge}$ neva 4, Switzerland. the neural tissue. Therefore, important questions about the possible role of toxic substances or a defect in trophic factors in neurological diseases cannot be addressed in a simple manner. An in vitro preparation composed of human tissue may be a useful tool for the characterization of the conditions necessary for neuronal survival, the testing of pathological material, and the study of pharmacological agents.

A suitable system to achieve these goals is the dissociated monolayer culture of neural tissue. Although the cellular organization in this preparation differs from the in vivo situation, it permits the best possible control of the extracellular environment. So far, longterm cultures of human spinal cord tissue have been reported in explants (Peterson et al., 1965; Hösli et al., 1973, 1974). We report here that dissociated spinal cord cells from 8- to 9-week-old human embryos can survive for up to 7 wccks in monolayer cultures. Another objective of this study was to evaluate the similarity between spinal cord cultured from human material and that from other species. Our biochemical and electrophysiological results suggest a high degree of similarity.

\section{Materials and Methods}

Preparation of cell cultures. Seven- to 10 -week-old human embryonic material was obtained from aspiration abortions at the Geneva Cantonal Hospital. Appropriate consent forms for experimental use of embryonic tissues were obtained from the Ethics Commission of the Department of Gynecology and Obstetrics. The age of the embryo was estimated according to menstrual history, foot size (Streeter, 1920), and external characteristics (Moore, 1982). The material was kept at $4^{\circ} \mathrm{C}$ for 2 to $6 \mathrm{hr}$ until dissection. The spinal cords were carefully isolated, all the spinal roots were removed, and the meninges and other adhering tissue were discarded. The cords were minced and incubated in 0.12 to $0.25 \%$ trypsin in $\mathrm{Ca}^{2+}, \mathrm{Mg}^{2+}$-free salt solution for $6 \mathrm{~min}$ at $37^{\circ} \mathrm{C}$. The cells were dispersed into a suspension by repeated trituration through a fire-polished Pasteur pipette. Cells were centrifuged ( $156 \times g ; 6 \mathrm{~min})$ and resuspended in culture medium. The yield from one 8- to 9-week-old embryonic spinal cord was approximately $4 \times 10^{6}$ spinal cord cells.

The Petri dishes were coated with rat-tail collagen and then dried (Bornstein, 1958); the plates were covered with a solution of polyornithine at a concentration of $1 \mathrm{mg} / \mathrm{ml}$ for $1 \mathrm{hr}$ and rinsed three times with phosphatebuffered saline solution (PBS) ${ }^{3}$ before plating. Unless otherwise indicated, 7

\footnotetext{
${ }^{3}$ The abbreviations used are: $\mathrm{ACh}$, acetylcholine; $\wedge \mathrm{CHC}$, aminocyclo hexane carboxylic acid; $A C h E$, acetylcholinesterase; ACCOA, acetylcoenzyme A; 4-AP, 4-aminopyridine; araC, arabinosylcytosine; $\mathrm{BrACh}$, bromoacetylcholine; CAT, choline acetyltransferase; DRG, dorsal root ganglion; FUdR fluorodeoxyuridine: GABA, $\gamma$-aminobutyric acid; GAD, glutamic acid decar boxylase; GFAP, glial acidic fibrillary protein; $L D H$, lactate dehydrogenase MEM, Eagle's minimum essential medium; MND, motor neuron disease; PBS phosphate-buffered saline; TTX, tetrodotoxin.
} 
$\times 10^{4}$ cells were seeded onto glass or plastic coverslips (Aclar, $10 \mathrm{~mm}$ diameter) prepared according to the method of O'Lague et al. (1978), $8 \times$ $10^{5}$ cells were seeded onto $35-\mathrm{mm}$ tissue culture dishes, $3 \times 10^{5}$ cells were seeded onto $16-\mathrm{mm}$ tissue culture wells, and 5 to $7 \times 10^{4}$ cells were seeded onto $11-\mathrm{mm}$ tissue culture wells. The cultures were maintained at $37^{\circ} \mathrm{C}$ in $10 \% \mathrm{CO}_{2} / 90 \%$ air. The medium was changed every 3 days.

Culture medium. The growth medium contained Eagle's minimum essential medium (MEM) supplemented with heat-inactivated human serum $(20 \%$ $\mathrm{v} / \mathrm{v}), \mathrm{NaHCO}_{3}(27 \mathrm{~mm}), \mathrm{KCl}(30 \mathrm{~mm})$, glutamine $(2 \mathrm{~mm})$, glucose $(0.6 \%)$, penicillin $(50$ units $/ \mathrm{ml})$, and streptomycin $(50 \mu \mathrm{g} / \mathrm{ml})$. The osmolarity of the medium was adjusted to 310 mOsm by adding double-distilled water. The final concentration of the human serum was $13.3 \%(\mathrm{v} / \mathrm{v})$, and the $\mathrm{KCl}$ concentration was $23.6 \mathrm{~mm}$.

Human serum. Blood was obtained by venipuncture from voluntary blood donors at the Transfusion Center of the Geneva Cantonal Hospital. The serum was prepared by centrifugation at $1000 \times \mathrm{g}$ for $15 \mathrm{~min}$ at room temperature. The samples were pooled, centrifuged $1 \mathrm{hr}$ at $7470 \times \mathrm{g}$. aliquoted, and stored frozen at $-80^{\circ} \mathrm{C}$. Aliquots were thawed and heat inactivated for $30 \mathrm{~min}$ at $56^{\circ} \mathrm{C}$ prior to preparation of the medium.

Acety/cholinesterase staining. Cultures were stained for acetylcholinesterase (AChE) by the technique of Karnovsky and Roots (1964).

Cell counting. An average of 20 randomly chosen fields per well were observed at $\times 160$ or $\times 250$ magnification under phase contrast illumination. A photograph $(16 \times 25 \mathrm{~cm})$ of each field was taken and the neurons were counted. Twenty fields represented $2 \%$ of the surface area of each $16-\mathrm{mm}$ culture well. Three wells were counted for each time point. All phase-bright cells with one or more processes were counted as neurons.

Indirect immunofluorescence techniques. The detection of tetanus toxin receptors was done using the method described by Mirsky et.al. (1978). The toxin and the anti-tetanus toxoid serum were a gift from Dr. C. Ziller, Nogentsur-Marne, France. Staining with antibodies for glial fibrillary acidic protein (GFAP) and neurofilament protein was done according to the technique of Prochiantz et al. (1982). The monoclonal antibody to GFAP (anti-GFAP 3) was a gift from Dr. E. Bock, Copenhagen, Denmark, and the GFAP had been prepared from normal human brain (Albrechtson et al., 1984). The monoclonal antibody to neurofilaments (RT97) was a gift from Dr. B. Anderton, London, England (Anderton et al., 1982).

Acetylcholine synthesis and accumulation. The assay was performed according to the method described by Kato and Rey (1982). The final $\mathrm{KCl}$ concentration in all synthesis experiments was reduced to $3.6 \mathrm{~mm}$. The final spccific activity of the $\left[\right.$ methyl $\left.{ }^{3} \mathrm{H}\right]$ choline $(78 \mathrm{Ci} / \mathrm{mmol})$ in the incubation medium was 0.15 to $1.09 \mathrm{Ci} / \mathrm{mmol}$. Throughout the text, the term "synthesis of $\left[{ }^{3} \mathrm{H}\right] \mathrm{ACh}$ " refers to the synthesis and accumulation of the transmitter by intact cells in culture.

These same methods were used for measuring the synthesis of $\left[{ }^{3} \mathrm{H}\right]-\gamma$ aminobutyric acid $\left(\left[{ }^{3} \mathrm{H}\right] \mathrm{GABA}\right)$ and $\left[{ }^{3} \mathrm{H}\right]$ norepinephrine. The final specific activity of $\left[{ }^{3} \mathrm{H}\right]$ glutamic acid and $\left[{ }^{3} \mathrm{H}\right]$ tyrosine was $0.33 \mathrm{Ci} / \mathrm{mmol}$. Ascorbic acid was added to the incubation medium containing $\left[{ }^{3} \mathrm{H}\right]$ tyrosine at a concentration of $0.01 \%$

Choline acetyltransferase assays. Choline acetyltransferase (CAT) was determined by measuring the synthesis of $\left[{ }^{3} \mathrm{H}\right] \mathrm{ACh}$ from $\left[{ }^{3} \mathrm{H}\right]$ acetylcoenzyme A (AcCOA). The CAT measurements were done according to the method of Fonnum (1975) with minor modifications.

Glutamic acid decarboxylase. When CAT, glutamic acid decarboxylase (GAD), and lactate dehydrogenase (LDH) were determined in the same cultures, the cells were scraped in $100 \mu \mathrm{l}$ of homogenizing medium composed of $0.01 \mathrm{M} \mathrm{Tris-HCl}(\mathrm{pH} 6.8)$ and $0.2 \%$ Triton X-100. The homogenate was diluted 2- or 3-fold with sodium phosphate buffer $(\mathrm{pH} \mathrm{6.4)}$ when the cells were plated in 11- and 16-mm wells, respectively. Five microliters of the homogenate were added to the reaction mixture $(35 \mu \mathrm{l})$ composed of 4.6 $\mathrm{mM}\left[{ }^{3} \mathrm{H}\right]$ glutamic acid $(21 \mu \mathrm{Ci} / \mu \mathrm{mol}), 0.23 \mathrm{~mm}$ pyridoxal phosphate, $1.14 \mathrm{~mm}$ 2.aminoethylisothiouronium bromide hydrobromide, and $0.06 \mathrm{M}$ sodium phosphate buffer, $\mathrm{pH} 6.4$. After $20 \mathrm{~min}$ at $37^{\circ} \mathrm{C}$, the reaction was stopped by the addition of $10 \mu \mathrm{l}$ of electrophoresis buffer $(0.47 \mathrm{M}$ formic acid and $1.4 \mathrm{M}$ acetic acid, $\mathrm{pH} \mathrm{1.9)} \mathrm{containing} 10 \mathrm{mg} / \mathrm{ml}$ of unlabeled sodium glutamate and GABA. At this point the samples could be frozen at $-80^{\circ} \mathrm{C}$. Subsequently the entire sample was applied to $3 \mathrm{MM}$ Whatman paper and separated by high voltage electrophoresis at $4500 \mathrm{~V}$ for $2 \mathrm{hr}, 15 \mathrm{~min}$. The rest of the procedure was identical to the one used for $\left[{ }^{3} \mathrm{H}\right] \mathrm{ACh}$ synthesis measurements (Kato and Rey, 1982)

Lactate dehydrogenase assays. The LDH assay was performed according to the method described by Kornberg (1955)

Uptake of $\left.{ }^{3} H\right] G A B A$ and autoradiography. The methods for studying GABA uptake were similar to those described by Farb et al. (1979). The identity of the radioactivity accumulated was assured by high voltage electrophoresis as described by Kato and Rey (1982). Ninety-six percent of the radioactivity found on the paper co-migrated with cold GABA.
For autoradiography, the cells were cultured for 14 to 19 days; they were rinsed and incubated at $37^{\circ} \mathrm{C}$ for $45 \mathrm{~min}$ with $\left[{ }^{3} \mathrm{H}\right] \mathrm{GABA}(70 \mathrm{Ci} / \mathrm{mmol})$, plus $1 \mathrm{~mm} \beta$-alanine or aminocyclohexane carboxylic acid (ACHC). The cells were then washed in PBS and fixed in $2.5 \%$ glutaraidehyde in PBS for 30 min The coverslips were mounted on slides, coated with llford L-4 emulsion diluted $1: 1$ with water, exposed for 10 days at $-20^{\circ} \mathrm{C}$, developed with Kodak D-19, and fixed in llford Rapid Fixer.

Electrophysiology. The procedures for superfusing the cultures during electrophysiological experiments are the same as previously described (Bader et al., 1983). Temperature in the dish was $31^{\circ} \mathrm{C}$. The perfusion rate was $0.5 \mathrm{ml} / \mathrm{min}$. The control superfusion solution was MEM with added glutamine ( $2 \mathrm{~mm}$ ), glucose $(3 \mathrm{~mm})$, penicillin $(50$ units $/ \mathrm{ml})$, streptomycin (50 $\mu \mathrm{g} / \mathrm{ml})$, bovine serum albumin $(20 \mu \mathrm{g} / \mathrm{ml})$ and $\mathrm{CaCl}_{2}(2 \mathrm{mM}$; final concentration, $3.8 \mathrm{~mm}$ ). The blocking agents tetrodotoxin, tetraethylammonium (TEA) and 4-aminopyridine (4-AP) were added to the control solution when required In experiments in which cobalt was used, a medium without phosphate salt was prepared. Recordings were made with the whole cell recording technique (Hamill et al., 1981). The recording procedure was as previously described (Bader et al., 1983). The solutions inside the patch pipette are described in the figure legends.

Media and chemicals. MEM, fetal calf serum, and trypsin were purchased from Grand Island Biological Co. (Grand Island, NY). Penicillin was obtained from Novo Industrie (Copenhagen, Denmark) and streptomycin was from Protochemie (Mitlödi, Switzerland). Tissue culture dishes were purchased from Falcon, 24-well tissue culture clusters $(16 \mathrm{~mm})$ were from Costa (Cambridge, MA), and 4-well tissue culture multi-dishes $(16 \mathrm{~mm}$ ) were from Nunc (Kamstrup, Denmark). Aclar sheets were purchased from Allied Chemical Corp. (Morristown, NJ). [ $\left.{ }^{3} \mathrm{H}\right] \mathrm{AcCoA}(1.1 \mathrm{Ci} / \mathrm{mmol})$ was purchased from New England Nuclear (Boston, MA). 4-Amino-N-[2,3-3 $\left.{ }^{3}\right]$ butyric acid $(70 \mathrm{Ci}$ ) mirnol), $\left[{ }^{3} \mathrm{H}\right]$ choline chloride $(78 \mathrm{Ci} / \mathrm{mmol}), \mathrm{L}-\left[\mathrm{G}-{ }^{3} \mathrm{H}\right]$ glutamic acid $(45 \mathrm{Ci} / \mathrm{mmol})$, and $\mathrm{L}-\left[2,3,5,6{ }^{3} \mathrm{H}\right] \mathrm{tyrosine}(104 \mathrm{Ci} / \mathrm{mmol})$ were purchased from Amersham/ Searle (Buckinghamshire, England). The rabbit anti-mouse IgG conjugated to tluorescein was purchased from Miles Laboratories, Elkhart, $\mathbb{N}$, arabinosylcytosine (araC) and tetrodotoxin were from Calbiochem, fluorodeoxyuridine (FUdR) was from Sigma Chemical Co. (St. Louis, MO), and 4-AP and TEA were from Fluka (Buchs, Switzerland). Bromoacetylcholine (BrACh) was a gift of Dr. S. Tucek (Prague), and ACHC was a gift of Dr. N. Bowery (London)

\section{Results}

Growth of the cultures. Dissociated human spinal cord cells from 8- to 9-week-old embryos attached within a few hours to the pretreated surface. Within $24 \mathrm{hr}$, there were small processes extending from the cells and these increased in length and thickness with time in culture. The non-neuronal cells became recognizable only after 3 days and these cells became confluent after 2 weeks in culture. After 7 weeks in culture the neuronal cells could still be recognized and they remained viable as judged by electrophysiolog ical criteria.

Figure 1 shows a photograph of human spinal cord cells prepared from 8-week-old embryonic tissue and cultured for 13 days. Processes are seen to extend from the neuronal cell bodies and appear to grow on top of the non-neuronal cells. In the presence of collagen alone as a substrate, the cells form small aggregates with networks of neurites between the cell masses. In four separate experiments, the number of neurons was determined after 9 to 21 days in culture; the neurons represented approximately $16 \%$ of the total number of spinal cord cells plated.

The neurons grow in the presence of a standard tissue culture medium (MEM) that contains 13\% decomplemented human serum and $25 \mathrm{mM} \mathrm{KCl}$. Elevated $\mathrm{KCl}$ has been shown to increase the neuronal survival in cultures of central and peripheral nervous system (Lasher and Zagon, 1972; Chalazonitis and Fischbach, 1980); in our culture preparation, there is a 2 -fold increasc in CAT activity with 25 $\mathrm{mM} \mathrm{KCl}$ as compared to $5.4 \mathrm{mM} \mathrm{KCl}$ in the culture medium. When the serum was not decomplemented, there were many fewer neurons surviving and there was a 30 to $60 \%$ decrease in the synthesis of $\left[{ }^{3} \mathrm{H}\right] \mathrm{ACh}$ as compared to cultures with non-decomplemented serum after 2 weeks in culture. Also, the neurons do not survive in two types of artificial medium, $\mathrm{N}_{2}$ (Bottenstein and Sato, 1979) and a medium described by Brazeau et al. (1981), both of which have 


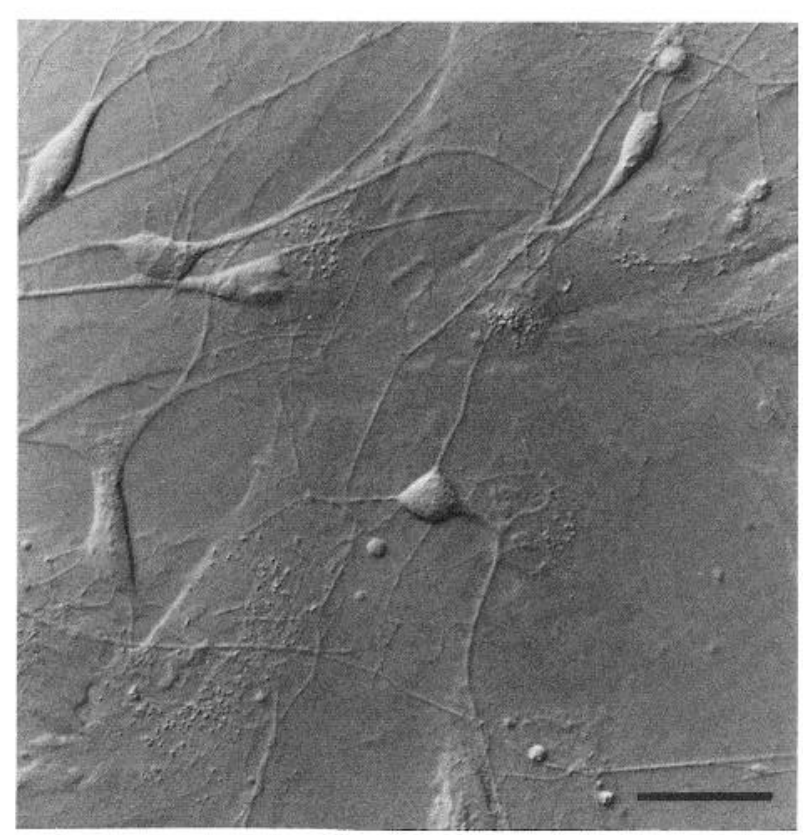

Figure 1. Dissociated human spinal cord cells in culture for 13 days. The photograph was taken with Nomarski optics. Bar $=30 \mu \mathrm{m}$.

been shown to support the survival of other types of cultured neurons. In addition, the cells do not survive in the absence of serum.

Histochemical properties of human spinal cord neurons. Phase contrast examination suggested that at least two categories of cells were present: neuron-like cells and non-neuronal cells. The goal of the present study was not to characterize in detail all cell types but simply to demonstrate by histochemical techniques that neurons and non-neuronal cells were present. We have used two markers to label neuronal cells: tetanus toxin and a monoclonal antibody against neurofilament protein.

Figure $2 A$ shows the binding of tetanus toxin to a cell in a 14-dayold culture using indirect immunofluorescence. The cells that could be classified as neurons on the basis of phase contrast examination (i.e., long processes and refractile cell bodies) were labeled in the presence of the toxin. However, a few cells with a non-neuronal morphology were also faintly labeled. Figure $2 B$ shows a similar culture, but in this case the cells were labeled with a monoclonal antibody for neurofilament protein. This antiserum also labeled all cells that would have been classified as neurons by phase contrast optics. Using this antiserum, we did not get any labeling of cells with a non-neuronal morphology apart from a nuclear binding. This appears to be one of the properties of this monoclonal antibody (B. $\mathrm{H}$. Anderton, personal communication).

The cultures were also stained for AChE to determine whether a subpopulation of neuronal cells could be identified. In cultures prepared from 8-week-old embryonic spinal cord, there was very little AChE staining until 15 days in culture. After 3 weeks in culture, most of the neurons were marked either intensely or moderately (Fig. 2C), and the intensely labeled cells often formed small aggregates as shown in Figure $2 D$. The cell bodies rather than the neurites exhibited the brownish stain characteristic of this reaction. In general, cells with the morphological appearance of non-neuronal cells did not stain for AChE. When the cultures were treated in the presence of eserine $(100 \mu \mathrm{M})$ to inhibit the enzymatic reaction, there were virtually no labeled cells. Similar results have been reported by Hösli et al. (1974) using explant cultures of human spinal cord. They observed that neurons in spinal cord cultures prepared from older fetuses (12 to 18 weeks) had a higher AChE content than those prepared from younger fetuses ( 8 weeks).
Both glial cells and fibroblasts might be expected to be present among the population of non-neuronal cells. We tested for the presence of GFAP, a marker that is quite specific for astrocytes. A population of non-neuronal cells was marked by the antibody. for GFAP (Fig. $3 A$ ). These cells had a flattened morphology with both thin and thick cytoplasmic processes. Astrocytes were usually situated in the areas where there were large numbers of neuronal cells (Fig. 3B).

Effects of antimitotic agents. We have used the antimitotic agents, araC and FUdR, in an attempt to eliminate the non-neuronal cells. This would have been advantageous for the long-term survival of the cultures since the overgrowth by the non-neuronal cells causes the cultures to detach after several weeks. Two different concentrations of FUdR were tested on the spinal cord cultures between days 3 and 5; these were compared to control cultures that had no antimitotic treatment and to cultures treated with araC. After 15 days in culture, the levels of $\mathrm{LDH}, \mathrm{GAD}$, and CAT activity were determined.

Using phase contrast optics, the morphology of the neurons in all four conditions was indistinguishable, but the number of non-neuronal cells had decreased in the presence of the antimitotics. As shown in Table I, there was no difference in the number of neurons surviving following antimitotic treatment, but all three enzymatic activities had decreased. This decrease was higher with araC than with FUdR. In a separate series of experiments, we have also found that the synthesis of $\left[{ }^{3} \mathrm{H}\right] \mathrm{ACh}$ decreases in the cultures following treatment with $\operatorname{araC}(10 \mu \mathrm{M})$. Therefore, even though the number of surviving neurons is not altered by the antimitotic treatment, there is an important decrease in the level of the two enzymes responsible for neurotransmitter synthesis. For these reasons, we have not used araC or FUdR in the spinal cord cultures.

Cholinergic properties of the cultured neurons. Since we are interested in obtaining cultures of human motoneurons for the study of Motor Neuron Disease (MND), it was important to assess the presence of cholinergic neurons in the cultures. As cholinergic markers, we have examined the activity of the enzyme CAT in cell homogenates and the ability of intact cells to synthesize and store $\left[{ }^{3} \mathrm{H}\right] \mathrm{ACC}$ using extracellular $\left[{ }^{3} \mathrm{H}\right]$ choline as a precursor.

CAT levels were determined in spinal cord cells cultured for 7 to 13 days; the average enzymatic activity from seven experiments was $65 \pm 1 \mathrm{pmol}$ of $\left[{ }^{3} \mathrm{H}\right] \mathrm{ACh}$ synthesized $/ 100,000$ cells plated/hr. The specificity of the enzymatic reaction was demonstrated by the use of a specific inhibitor of CAT (Tucek, 1982), BrACh. In the presence of $2 \mu \mathrm{M} \mathrm{BrACh}$, the enzymatic activity was inhibited by $82 \%$.

The kinetics of $\left[{ }^{3} \mathrm{H}\right] \mathrm{ACC}$ synthesis using $\left[{ }^{3} \mathrm{H}\right]$ choline as a precursor were analyzed in order to determine optimal conditions for the time of incorporation of the precursor and also the concentration of the precursor in the culture medium. The synthesis and accumulation of $\left[{ }^{3} \mathrm{H}\right] \mathrm{ACC}$ reached a plateau at approximately $100 \mathrm{~min}$ and at a choline concentration of 100 to $200 \mu \mathrm{M}$. Therefore, in subsequent experiments, an incorporation time of $60 \mathrm{~min}$ and a choline concentration of $100 \mu \mathrm{M}$ were chosen as standard conditions for $\left[{ }^{3} \mathrm{H}\right] \mathrm{ACh}$ synthesis. These results agree with those reported by Berg (1978) for dissociated cultures of chick spinal cord cells.

The number of spinal cord cells plated varied from one experiment to the next. Consequently, we determined whether $\left[{ }^{3} \mathrm{H}\right] \mathrm{ACh}$ synthesis in spinal cord cells was directly proportional to the number of cells initially plated. Over the range of $10^{5}$ to $4 \times 10^{5}$ cells plated/ 16-mm well, the rate of synthesis determined after 19 days in culture increased linearly from 0.4 to $2.5 \mathrm{pmol}$ of $\left[{ }^{3} \mathrm{H}\right] \mathrm{ACh} / \mathrm{dish} / \mathrm{hr}$.

We were interested in the development of the cholinergic neurons in these human spinal cord cultures. A possible complication in evaluating this development is the occurrence of neuronal death. Cell death may selectively affect cholinergic cells but could also affect all neurons and non-neuronal cells. To examine this issue, we have measured three parameters as a function of time in culture: $(i)$ we counted the number of neuron-like cells at various times to determine the neuronal survival, (ii) we measured CAT activity as a 

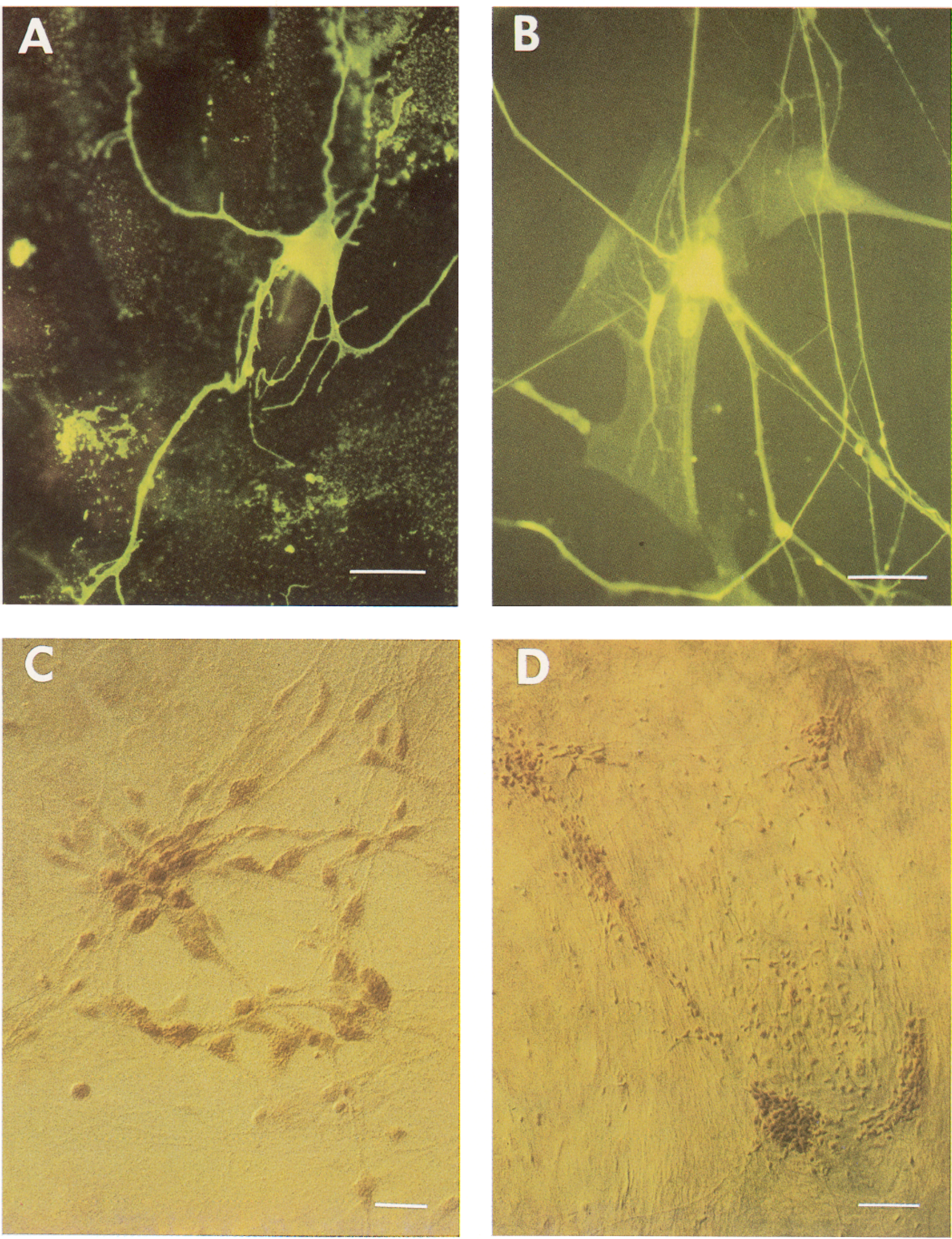

Figure 2. Immunofluorescence staining of tetanus toxin $(A)$, neurofilament protein $(B)$, and staining of $A C h E(C$ and $D)$ in cultures of human spinal cord. In $A$ the cells were cultured for 14 days $($ bar $=22 \mu \mathrm{m})$, in $B$ for 21 days $($ bar $=44 \mu \mathrm{m})$, in $C$ for 14 days $($ bar $=22 \mu \mathrm{m})$, and in $D 14$ days $($ bar $=91 \mu \mathrm{m})$. The staining for AChE using acetylthiocholine was done for $24 \mathrm{hr}$ in $C$ and $2 \mathrm{hr}, 45 \mathrm{~min}$ in $D$. 

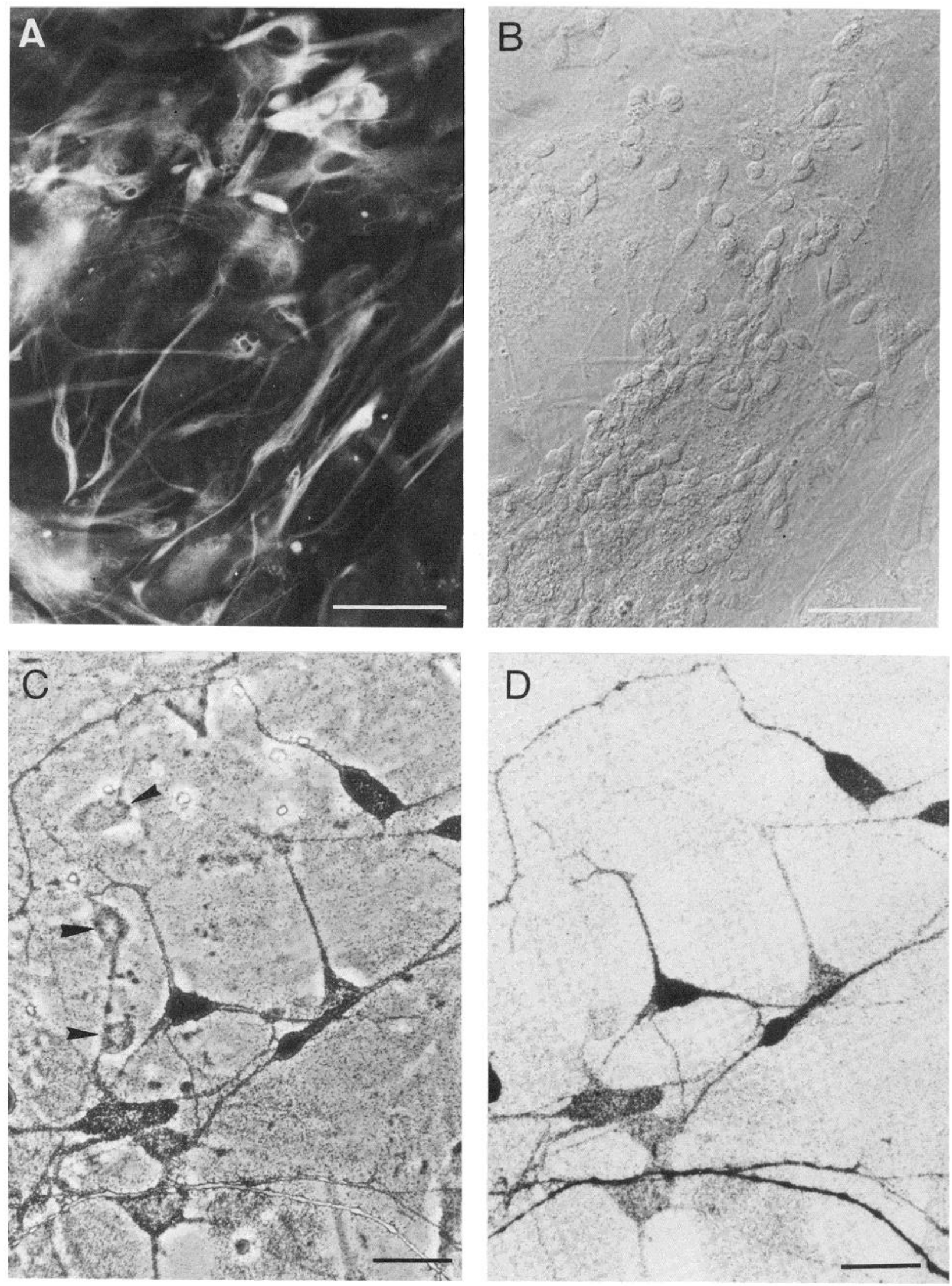

Figure 3. $A$, Immunofluorescence staining of GFAP in cultures of human spinal cord grown for 13 days. $B$, The same field photographed with interference contrast optics. Bars $(A$ and $B)=50 \mu \mathrm{m}$. Phase contrast $(C)$ and brightfield $(D)$ autoradiographs of a 15-day-old culture exposed to $0.1 \mu \mathrm{M}\left[{ }^{3} \mathrm{H}\right] \mathrm{GABA}$ for $1 \mathrm{hr}$. Arrowheads in $\mathrm{C}$ indicate the neurons that are not labeled by $\left[{ }^{3} \mathrm{H}\right] \mathrm{GABA}$. Exposure time was 13 days. Bars $(C$ and $D)=30 \mu \mathrm{m}$. 
TABLE I

Neuronal survival, GAD, and CAT in cultures treated with antimitotics

Human spinal cord cells $\left(6 \times 10^{5}\right.$ cells) were cultured in $16-\mathrm{mm}$ wells. Triplicate cultures were treated from day 3 to day 5 with $(i)$ no antimitotic, (ii) FUdR $(5 \mu \mathrm{g} / \mathrm{ml})$, (iii) FUdR $(20 \mu \mathrm{g} / \mathrm{ml})$, and (iv) araC (10 $\mu \mathrm{M})$. The neurons were counted after 15 days in culture; subsequently the cells were scraped and the I $\mathrm{DH}, \mathrm{GAD}$, and CAT were measured per culture. The total enzymatic activities measured in the cultures are expressed as percentages of the values found in control dishes which are taken as $100 \%$. The controls did not receive araC or FUdR. Each value represents the mean of three sister cultures \pm SEM. The difference between the mean number of neurons in the experiments in the presence of the drugs as compared to the control is not significant. The null hypothesis in the $t$ test cannot be rejected ( $p$ between 0.1 and 0.95 ).

\begin{tabular}{lcrrr}
\hline Conditions & No. of Neurons Surviving $\times 10^{-3}$ & \multicolumn{1}{c}{ LDH } & \multicolumn{1}{c}{ GAD } & \multicolumn{1}{c}{ CAT } \\
\hline Control & $85 \pm 3$ & $100 \pm 3$ & $100 \pm 7$ & $100 \pm 4$ \\
FUdR & $86 \pm 5$ & $65 \pm 3$ & $76 \pm 6$ & $48 \pm 6$ \\
$(5 \mu \mathrm{g} / \mathrm{ml})$ & $94 \pm 6$ & $58 \pm 3$ & $83+1$ & $55 \pm 4$ \\
FUdR & & & & \\
$(20 \mu \mathrm{g} / \mathrm{ml})$ & $76 \pm 4$ & $35 \pm 3$ & $62 \pm 6$ & $22 \pm 2$ \\
$\operatorname{araC}$ & & & & \\
$(10 \mu \mathrm{M})$ & & & & \\
\hline
\end{tabular}

cholinergic marker, and (iii) we determined $L D H$ activity as an index of the development of both neuronal and non-neuronal cells. The evolution of these three parameters over a 3-week period in culture is illustrated in Figure 4. The number of neuronal-like cells counted over this period remained virtually constant. The level of CAT increased 2.5-fold from day 3 to day 21 , showing that there was a development of this cholinergic activity in the cultures. In another series of experiments, we also found that the synthesis of $\left[{ }^{3} \mathrm{H}\right] \mathrm{ACh}$ increased 1.4-fold over 15 days in culture. In addition, $\mathrm{LDH}$ activity increased linearly 4.1 -fold during the same period, reflecting the development of both the neuronal and non-neuronal cell population.

Although we have indications that cultured human spinal cord neurons include cholinergic cells, there is no direct way to assess that these cells are motoneurons. An experiment that indirectly addressed this question was to examine the ability of the anterior and posterior parts of the spinal cord to synthesize ACh. Since motoneurons are localized in the anterior horns, one might expect this part of the spinal cord to synthesize more ACh. In two experiments, the spinal cord was dissected into the anterior and posterior regions and the cells from these regions were cultured separately; the number of cells plated for each region was the same (Table II). The cells were cultured for 15 days and 12 days, respectively, and then analyzed for $\left[{ }^{3} \mathrm{H}\right] \mathrm{ACh}$ synthesis. In both experiments, the level of $\left[{ }^{3} \mathrm{H}\right] \mathrm{ACC}$ production was higher (3- to 5 -fold) in the cultures of the anterior region as compared to the posterior part.

Other nourotransmitters. The spinal cord contains many neurotransmitters besides ACh. Our goal was not to assess the presence of all of these neurotransmitters but to show that the cultures had the capacity to synthesize one other major spinal cord transmitter (i.e., GABA). In addition, it was also important to show that a neurotransmitter which is usually not prcsent in neuronal cell bodies of the spinal cord was not detectable in human spinal cord cultures. For this purpose, we tested the ability of the cells to synthesize norepinephrine from labeled tyrosine and to take up the transmitter.

Initially, we examined the ability of the human spinal cord cells to take up $\left[{ }^{3} \mathrm{H}\right] \mathrm{GABA}$. Cultures incubated in the presence of $0.1 \mu \mathrm{M}$ $\left[{ }^{3} \mathrm{H}\right] \mathrm{GABA}$ accumulated radioactivity linearly for the first $20 \mathrm{~min}$. The radioactivity was composed of $98 \%\left[{ }^{3} \mathrm{H}\right] \mathrm{GABA}$ as verified by high voltage electrophoresis. In the presence of amino-oxyacetic acid ( 1 $\mathrm{mm}$ ) (Currie and Dutton, 1980), an inhibitor of GABA transaminase, there was no difference in the total uptake of radioactivity. Therefore, this enzyme does not appear to play a significant role in the breakdown of GABA in the present system.

GABA can be taken up by neuronal as well as non-neuronal cells. Selective inhibitors can be used to distinguish between these two uptake mechanisms. Initial rates of $\left[{ }^{3} \mathrm{H}\right] \mathrm{GABA}$ uptake $(0.1 \mu \mathrm{M}, 20$ $\mathrm{min}$ ) were examined in cells cultured for 5,11 , and 14 days. In the presence of $\mathrm{ACHC}(1 \mathrm{~mm})$, an inhibitor of $\mathrm{GABA}$ uptake into neuronal cells (Bowery et al., 1976), there was approximately 80 to $90 \%$ inhibition of the uptake in 5- and 14-day-old cultures; this suggests that the fraction of GABAergic neurons remains constant. In contrast, $\beta$-alanine ( $1 \mathrm{mM}$ ) inhibitcd the uptake by approximately $26 \%$ in the celis cultured for 5 days and by approximately $45 \%$ in the cells

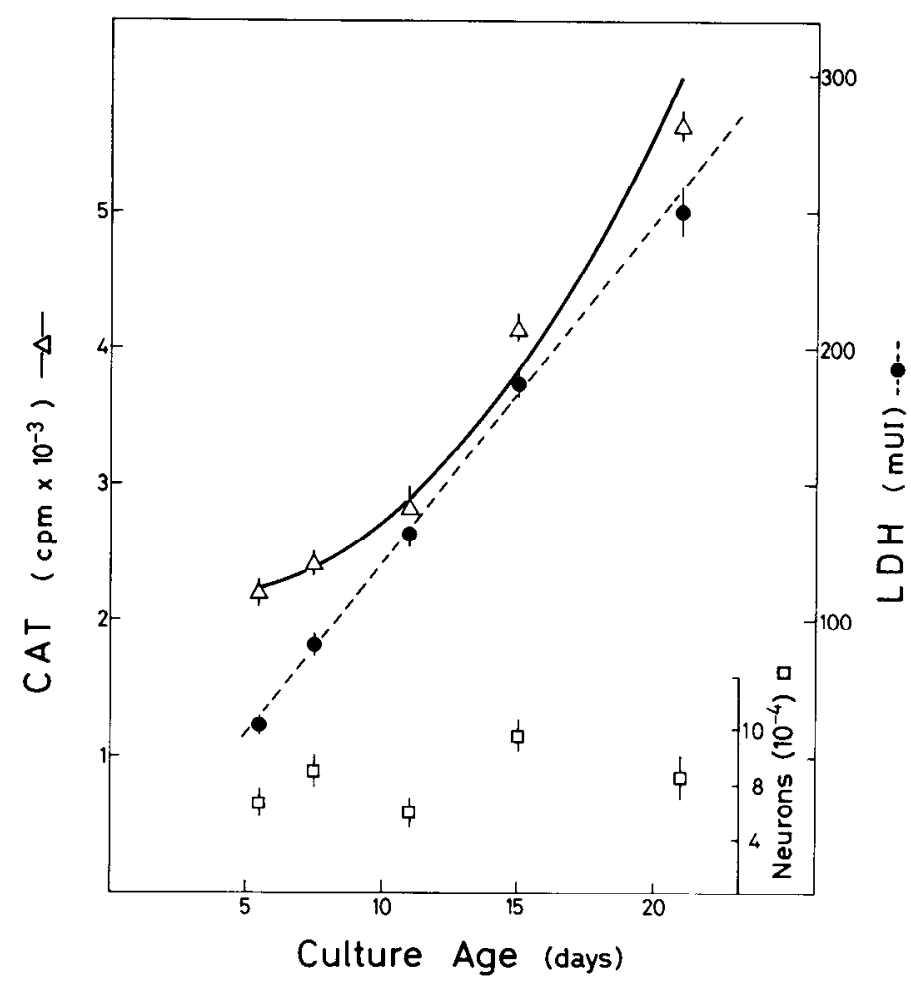

Figure 4. CAT, LDH, and number of neurons per well as a function of time in culture. Human spinal cord cells $\left(5.6 \times 10^{5}\right)$ from an 8-week-old embryo were cultured in $16-\mathrm{mm}$ wells for $5.5,7.5,11,15$, and 21 days. The cells were scraped in homogenizing medium and the LDH and GAD activities were measured immediately. The samples were frozen at $-80^{\circ} \mathrm{C}$ until the CAT levels were determined. In these experiments, the $\left[{ }^{3} \mathrm{H}\right] \mathrm{ACC}$ CA concentration was $1.2 \mu \mathrm{M}(1.1 \mathrm{Ci} / \mathrm{mmol})$; the activity is expressed in counts per minute rather than picomoles of $\mathrm{ACh}$ formed because we are not using a saturating concentration of the substrate ACCOA. However, with a higher specific radioactivity, the sensitivity of the reaction is increased (Weber et al., 1984). One milliunit ( $m U I)$ of $L D H$ is defined as that amount of enzyme which causes an initial rate of oxidation of $1 \mathrm{nmol}$ of $\mathrm{NADH} / \mathrm{min}$. Each point represents the mean of three sister cultures, and the bars indicate the SEM. Lines were drawn by eye.

\section{TABLE \|}

Comparison of $\left[{ }^{3} \mathrm{H}\right] \mathrm{ACh}$ synthesis and accumulation in cultures of the anterior and posterior regions of human embryonic spinal cord

In Experiment 1, a 9-week-old embryonic spinal cord was dissected into the anterior and posterior regions; after dissociation, $1.2 \times 10^{5}$ cells were plated per 16-mm dish for each region of the cord. After 15 days in culture, the cells wcre incubated in $100 \mu \mathrm{M}\left[{ }^{3} \mathrm{H}\right]$ choline for $1 \mathrm{hr}$, and the synthesis and storage of $\left[{ }^{3} \mathrm{H}\right] \mathrm{ACh}$ were determined. Each value represents the mean of two cultures \pm SEM. In Experiment 2, an 8-week-old embryonic spinal cord was dissected as above and, after dissociation. $2.5 \times 10^{5}$ cells were plated per 16-mm dish. After 12 days in culture, the cells were incubated in $100 \mu \mathrm{M}\left[{ }^{3} \mathrm{H}\right] \mathrm{choline}$. Each value represents the mean of throc cultures \pm SEM.

\begin{tabular}{ccc}
\hline \multirow{2}{*}{ Experiment } & \multicolumn{2}{c}{ pmol ACh $\times 10^{-5} \mathrm{cells} \times \mathrm{hr}^{-1}$} \\
\cline { 2 - 3 } & Anterior & Posterior \\
\hline 1 & $5.30 \pm 0.06$ & $1.78 \pm 0.05$ \\
2 & $1.05 \pm 0.05$ & $0.22 \pm 0.03$ \\
\hline
\end{tabular}


cultured for 11 and 14 days; this agent is known to block GABA uptake into non-neuronal cells (Kelly and Dick, 1976). Therefore, non-neuronal GABA uptake appears to increase with time in culture. This is consistent both with the morphological observation of nonneuronal cell proliferation and with the increase in LDH activity.

Given the observation that there was a GABA uptake by neuronal cells, we examined the fraction of the neuronal population that would be labeled after incubation with $\left[{ }^{3} \mathrm{H}\right] \mathrm{GABA}$. Figure $3, C$ and $D$, shows the pattern of labeling revealed by autoradiography of $\left[{ }^{3} \mathrm{H}\right] \mathrm{GABA}$ uptake into the spinal cord cultures. The neurons appear to grow on the top of a layer of non-neuronal cells; these neurons vary in size, and some are bipolar or multipolar. It is possible to distinguish three types of labeling with $\left[{ }^{3} \mathrm{H}\right] \mathrm{GABA}$ as shown in Figure $3 \mathrm{C}$ : four neurons are heavily labeled (very dense grains), five neurons are moderately labeled (individual grains distinguishable), and three neurons are not labeled (grain density slightly over background). When the cells were cultured for 14 to 19 days, $60 \%$ of the neurons were labeled ( 820 neurons counted for three separate platings). We did not observe any heavy labeling of non-neuronal cells. When the same cultures were incubated in the presence of $\left[{ }^{3} \mathrm{H}\right] \mathrm{GABA}$ plus $\mathrm{ACHC}$, there was no uptake into the neuronal cells. When $\mathrm{ACHC}$ was replaced by $\beta$ alanine, there was no difference in the uptake of $\left[{ }^{3} \mathrm{H}\right] \mathrm{GABA}$ into the neurons.

GABAergic cells can synthesize and accumulate $\left[{ }^{3} \mathrm{H}\right] \mathrm{GABA}$ using $\left[{ }^{3} \mathrm{H}\right]$ glutamate as a precursor (Hildebrand et al., 1971). Human spinal cord cells were indeed able to synthesize GABA after a 1 -hr incubation in $0.1 \mathrm{~mm}$ glutamate. In three different experiments using 8 or 9-week-old embryonic spinal cord cells cultured for 12 to 15 days, there were 1 to $5 \mathrm{pmol}$ of $\left[{ }^{3} \mathrm{H}\right] \mathrm{GABA}$ synthesized $/ 100,000$ cells plated.

We were unable to detect the presence of noradrenergic neurons in the human spinal cord cultured for 2 weeks. There was no synthesis of $\left[{ }^{3} \mathrm{H}\right]$ norepinephrine using $\left[{ }^{3} \mathrm{H}\right]$ tyrosine as a precursor, and there were no cells labeled by autoradiographic procedures following a 1 -hr incubation in the presence of $\left[{ }^{3} \mathrm{H}\right]$ norepinephrine. If there had been noradrenergic nerve fibers in the cultures, these would have degenerated after 2 weeks in culture.

Electrophysiological properties. Recordings were made with patch electrodes using the whole cell recording method (Hamill et al., 1981; Bader et al., 1983). Resting membrane potentials were relatively depolarized for cells considered as neurons; in 14 cells, the resting potential was $-38 \pm 9 \mathrm{mV}$ (mean $\pm \mathrm{SD}$ ), and the range was from -20 to $-53 \mathrm{mV}$. There was no indication that low resting potentials were due to cell lesions since cells with low resting potentials could have a high resistance and large membrane currents in voltage clamp. Passive membrane properties of human spinal cord neurons are given in Table III. Depolarizing current pulses which drove the potential beyond a critical level between -40 and -35 $\mathrm{mV}$ triggered short duration (approximately $2 \mathrm{msec}$ ) action potentials in most neurons. These action potentials could be blocked by a low concentration of tetrodotoxin (TTX).

Sodium current. Voltage clamp experiments indicated the presence of a sodium current. In Figure $5 A$, the voltage of a neuron was stepped from $-100 \mathrm{mV}$ to $0 \mathrm{mV}$ first while superfusing with a control solution and then with a solution containing $3.5 \mu \mathrm{M}$ TTX. It can be seen that TTX suppressed a fast inward current. A similar effect was observed when a neuron was superfused with a solution deprived of sodium ions (choline substitution). The effects of sodium removal and of TTX exposure were reversible. Similar results were obtained in 8 other cells. In 15 cells where peak inward sodium currents were measured, the mean value \pm SD was $1.4 \pm 0.6 \mathrm{nA}$. The relationship between peak inward sodium current and the voltage during a step is illustrated in Figure $5 B$. The sodium current activales near -40 $\mathrm{mV}$ and reaches an apparent reversal potential at $+43 \mathrm{mV}$.

In all preparations where a sodium current was investigated, the sodium current was found to be decreased by steady depolarized voltages, a property called inactivation which was originally reported in the squid axon (Hodgkin and Huxley, 1952). This property was also found in human neurons but will not be described in detail here.

\section{TABLE III}

Passive electrical properties of human spinal cord neurons

The data were obtained in neurons cultured for 19 days $(n=8)$ or 20 days $(n=4)$. Neurons originated from the same spinal cord and all recordings were done in two consecutive days. The capacitance $(C)$ was calculated either from the equation $C=\tau / R$ (charge of an $R-C$ circuit in current clamp), or from the relation $C=Q / \Delta V$ (number of electric charges in the initial capacitative current in a step of $\Delta \mathrm{V}$, in voltage clamp). The input resistance $(R)$ was measured from the slope of the linear region of current-voltage curves (see Fig. 5B). The apparent surface area $(A)$ was calculated by dividing the capacitance by a specific capacity of $1 \mu \mathrm{f} / \mathrm{cm}^{2}$; the values obtained are in good agreement with estimates of cell surface from microphotographs, where both cell soma and neurites are taken into account. The specific resistance $\left(R_{m}\right)$ was calculated as the product of $A$ and $R$.

\begin{tabular}{lrcrr}
\hline & $C(\mathrm{pf})$ & $R$ (megohms) & $A\left(\mu \mathrm{m}^{2}\right)$ & $R_{m}\left(\mathrm{ohm} \cdot \mathrm{cm}^{2}\right)$ \\
\hline Mean & 25 & 451 & 2,500 & 11,003 \\
SD & 7 & 127 & 700 & 2,723 \\
Range & $19-44$ & $270-660$ & $1,900-4,400$ & $7,290-16,016$
\end{tabular}

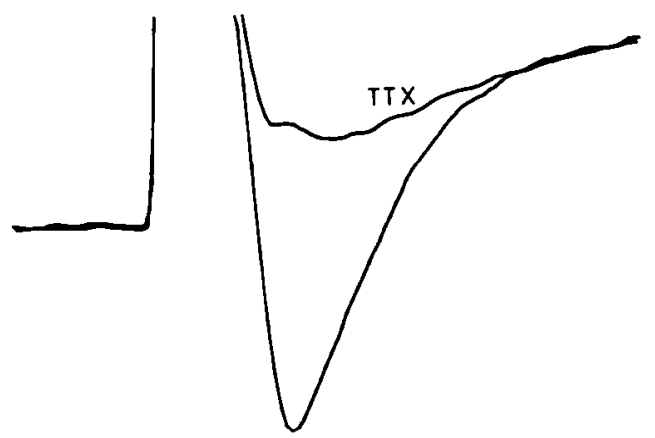

A
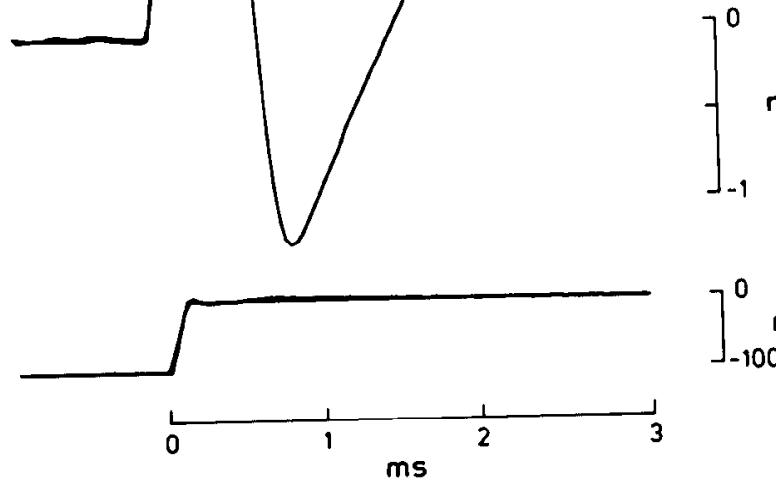

nA

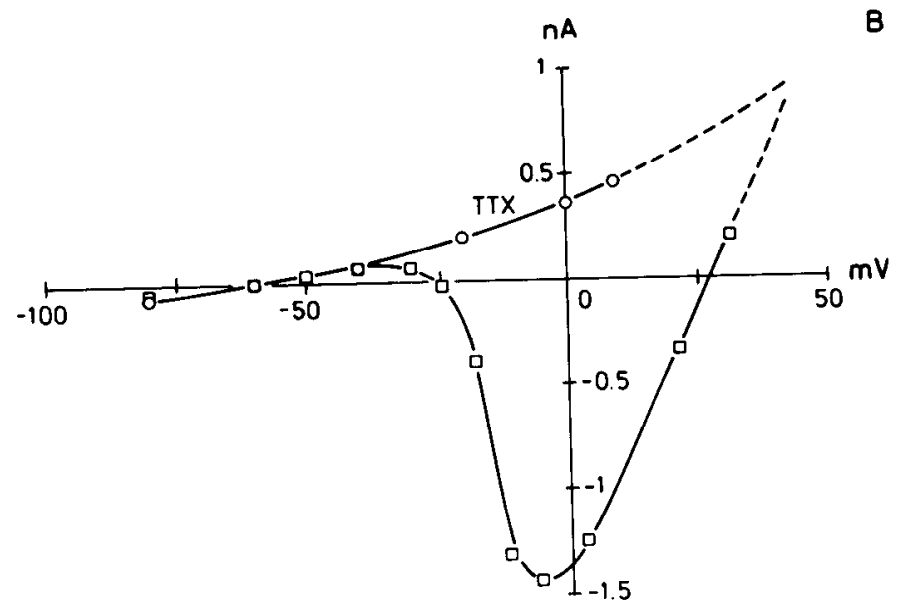

B

Figure 5. Sodium current in a human spinal cord neuron. $A$, Voltage clamp recording in a neuron cultured for 25 days. The solution inside the patch pipette was, in millimolar concentration: potassium acetate, $130 ; \mathrm{KCl}$, 20; HEPES, 5; glucose, 5; and EGTA, 5; the $\mathrm{pH}$ was 7.05 . The potential was stepped from a holding voltage of $-100 \mathrm{mV}$ to $0 \mathrm{mV}$ while superfusing first with control medium and then with a medium containing $3.5 \mu \mathrm{M}$ TTX. TTX suppressed an early inward current in a reversible manner. The initial upward and truncated peak is the current required to charge the membrane capacitance. $B$, Current-voltage relationship for the sodium current, using the sarne cell as in $A$. For each voltage step, minimum current was measured in the absence $(\square)$ and in the presence $(O)$ of TTX. The curves were drawn by eye. The intercept of the extrapolated curves represents the sodium reversal potential. 
Potassium current. Besides the sodium current, another current was activated by depolarizing voltage steps. In Figure 6 , the voltage of a neuron was stepped from $-100 \mathrm{mV}$ to one of several voltages $(+20,-10$, and $-30 \mathrm{mV})$, first in a solution containing TTX and then in a solution that contained $4 \mathrm{mM} 4-\mathrm{AP}$ in addition to TTX. It can be seen that 4-AP blocked an outward current. Similar experiments were performed in six other neurons. The effect of 4-AP was reversible. The ionic nature of this outward current was determined by examining tail currents (Fig. 7A). To eliminate any sodium current contribution, TTX was present in the superfusing solution. The voltage was stepped from -100 to $-5 \mathrm{mV}$ for $2 \mathrm{msec}$ and then stepped back to one of a series of voltages $(-50,-60,-70$, and $-90 \mathrm{mV}$, illustrated in Fig. 7A). Tail currents recorded at these final voltages relaxed to a stable value within $30 \mathrm{msec}$. Instantaneous currenls were plotted as a function of the final voltage in Figure $7 B$. $A$ line was drawn by eye through the data points. It can be seen that the line crosses the zero current axis at $-75 \mathrm{mV}$ which is the reversal potential for the examined current. In seven neurons the reversal potential was $-72 \pm 3 \mathrm{mV}$ (mean $\pm \mathrm{SD}$ ).

Increasing the extracellular potassium concentration 4-fold shifted this reversal potential. Table IV summarizes the results of three cells.
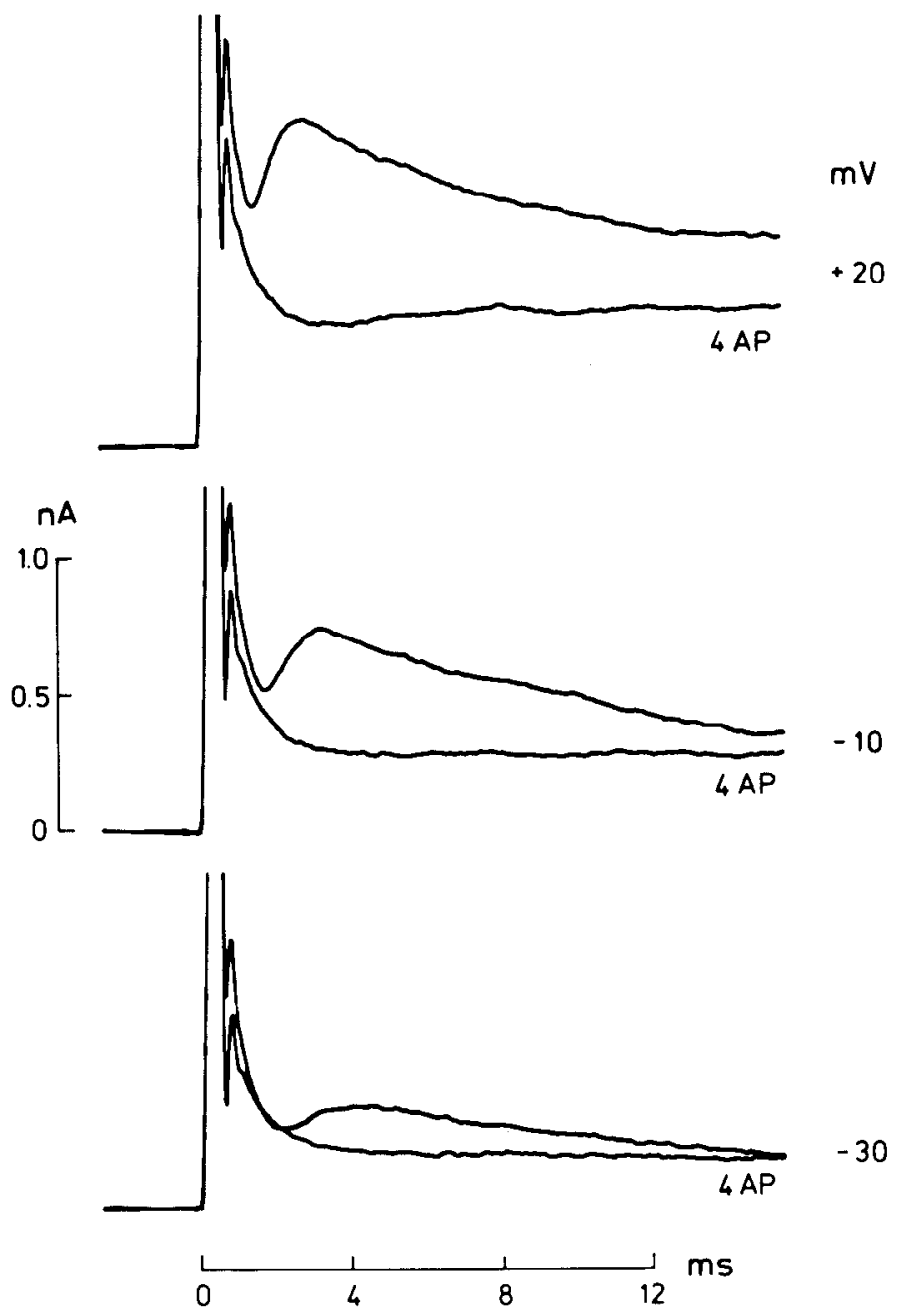

Figure 6. Effect of extracellular 4-AP on an outward current, from a neuron at 25 days in culture. The superfusion solution was a control medium that contained $5 \mu \mathrm{M}$ TTX to block the sodium current. The solution inside the patch pipette contained $\mathrm{KCl}(150 \mathrm{~mm})$ and EGTA $(5 \mathrm{~mm}, \mathrm{pH} 7.3)$. The cell was held in voltage clamp at $-100 \mathrm{mV}$ and stepped to the voltage indicated on the right of each pair of traces. The current recorded in the contro medium is the top trace in each pair. The superfusion medium was then substituted with one containing $4 \mathrm{~mm} 4$-AP, the voltage protocol was repeated, and the current was recorded (traces labeled 4-AP). The block with 4-AP was reversible (see also Fig. 8).
PA

$100-$
0
$-100^{200}$
$m$
0
$-100^{2}$
A
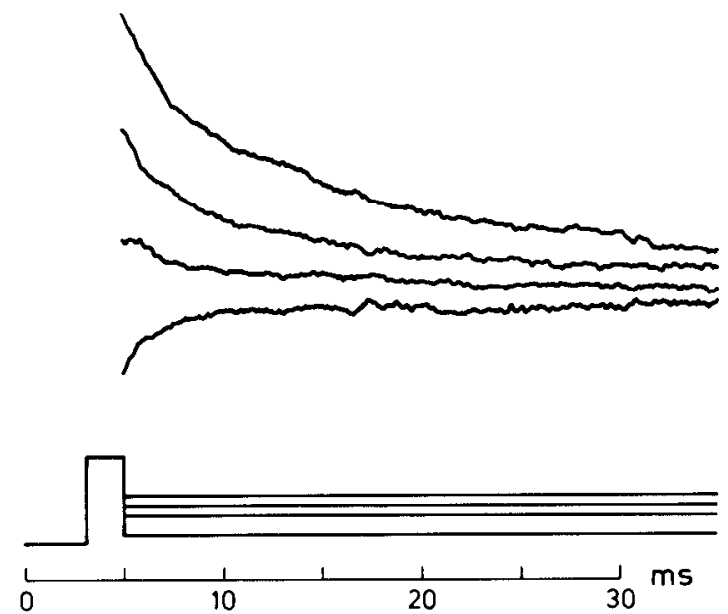

$p A$

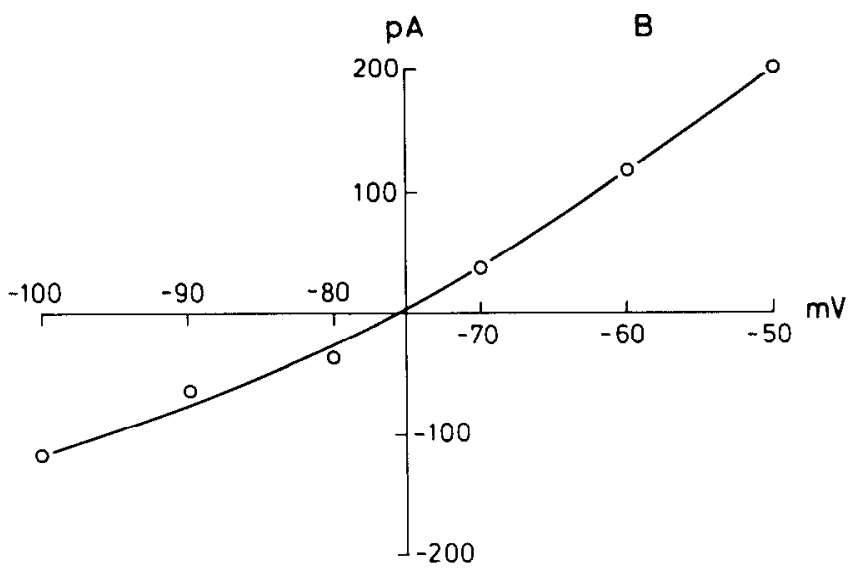

Figure 7. Reversal potential of the outward current from a neuron at 21 days in culture. Recording conditions were as in figure $6 . A$, The cell was held in voltage clamp at $-100 \mathrm{mV}$, then stepped for $2 \mathrm{msec}$ to $-5 \mathrm{mV}$ (see bottom trace) and stepped back to one of several final voltages $(-50,-60$, -70 , and $-90 \mathrm{mV}$ ). The step to $-5 \mathrm{mV}$ activated an upward current deflection of $600 \mathrm{pA}$ (not illustrated), and as the voltage was stepped back, the current relaxed to a steady value (tail currents). $B$, Instantaneous currents were plotted as a function of the final voltage. For each tail current, the steadystate $(30 \mathrm{msec})$ value was subtracted from the initial value $(6 \mathrm{msec})$; it represents the instantaneous current at the given voltage. A line was drawn by eye through the data. The intercept of this line with the zero current line represents the reversal potential of the current, here $-75 \mathrm{mV}$.

TABLE IV

Reversal potential of the potassium current at two different extracellular potassium concentrations

The reversal potential was measured (see Fig. 7) first in a solution that contained $5.4 \mathrm{~mm}$ potassium and then in a solution containing $21.6 \mathrm{~mm}$ potassium. The results are shown for three neurons. The shift is the difference between the reversal potentials in low and high extracellular potassium concentration. Predicted potassium equilibrium potential values calculated from the Nernst equation are given on the assumption that the intracellular potassium concentration is equal to the potassium concentration inside the pipette (150 mm) (see Fenwick et al. 1982; Bader and Bertrand, 1984).

\begin{tabular}{llll} 
& \multicolumn{2}{c}{ Reversal Potential $(\mathrm{mV})$} & \multirow{2}{*}{ Shift (mV) } \\
\cline { 2 - 3 } & $\mathrm{K}_{\text {out }}(5.4 \mathrm{~mm})$ & $\mathrm{K}_{\text {out }}(21.6 \mathrm{~mm})$ & \\
\hline Cell 1 & -73 & -47 & 25 \\
Cell 2 & -69 & -47 & 22 \\
Cell 3 & -71 & -45 & 26 \\
Mean \pm SD & $-71 \pm 2$ & $-46 \pm 1$ & $24 \pm 2$ \\
Predicted & -84 & -49 & 35 \\
\hline
\end{tabular}


It can be seen that the shift is smaller than expected for a selective potassium channel, but this is essentially due to the reversal potential value in $5.4 \mathrm{~mm}$ extracellular potassium which is more depolarized than predicted. This might be explained if some of the potassium ions leaving the cells during a depolarizing pulse remained in an "unstirred" layer close to the membrane. The effect of the corresponding slight increase in potassium concentration (on the order of 1 to $2 \mathrm{~mm}$ ) would obviously be more marked in the lower extracellular potassium concentration. Therefore, from these experiments we conclude that a depolarization of the neuronal membrane activates an outward current carried mainly by potassium ions.

Besides 4-AP, another potassium blocking agent, TEA, also reduced the potassium current (Fig $8 A$ ). The voltage of a cell was stepped from $-100 \mathrm{mV}$ to $+30 \mathrm{mV}$, and the current was recorded first while superfusing with a medium that contained no potassium blocking agent and then with a medium that contained either 20 or $40 \mathrm{~mm}$ TEA. The difference between the two concentrations of TEA is small, suggesting a saturation of the block by TEA. When the cell was finally superfused with a solution that contained 4-AP in addition to TEA, the potassium current was totally suppressed. Therefore, TEA removed a substantial amount of the potassium current but did not block all of it.

Figure $8 B$ is a recording in the same cell. The cell was allowed to recover from the full block illustrated in Figure $8 A$. Then the neuron was superfused with a solution containing 4-AP (4 mM). The block by 4-AP left a residual current that could be blocked by TEA. The results in Figure $8 A$ and $B$, are interesting in many respects. First, the magnitude of the current suppressed by a given drug (for example, 4-AP) depends on whether 4-AP is applied before or after TEA. The same statement applies for TEA. If there were two types of potassium channels, one would have to conclude that at least one of the two drugs can block both channels. Second, it is possible that two putative potassium channels can be distinguished on the basis of their kinetic properties. Since it appeared that a TEA concentration of $20 \mathrm{mM}$ was nearly saturating, the potassium current remaining in the presence of this concentration of TEA should correspond to the potassium current which is mainly sensitive to 4AP (Fig. $8 \mathrm{C}$, a). The kinetics of this current were determined by subtracting the current recorded during the full block (4-AP plus TEA) from the current recorded in the presence of $20 \mathrm{~mm}$ TEA. This current has a fast activation time course and decays quickly with time. The current that is mainly sensitive to TEA was obtained by subtracting current 4-AP,TEA from 4-AP (Fig. $8 B$ ) and is illustrated in Figure $8 C, b$. This current has a much slower time course of activation.

We found that the potassium current decayed with time during a depolarizing voltage step. The decay was actually composed of at least two time constants, a fast one which accounts for the decay observed in Figure 6 and a much slower one which leads to complete suppression of the potassium current over several seconds. This inactivation of the potassium current, which was observed in other preparations (see Connor and Stevens 1971a, b) will not be described in detail here.

Calcium current. The presence of a calcium current could only be detected when cells were superfused with a solution containing drugs that blocked the sodium and potassium currents. Even under these conditions the magnitude of the calcium current was generally small when compared to the sodium and potassium currents. In Figure $9 A$, the effect of a depolarizing pulse of current is shown in two different conditions. In the presence of extracellular calcium, the depolarization triggered a slow action potential. When extracellular calcium was replaced by cobalt, the action potential was suppressed and the current injection simply caused a passive voltage deflcction (Fig. 9A, Co). The blocking effect of cobalt was rapid and completely reversible.

Figure $9 B$ is a voltage clamp recording in the same cell. The voltage was first stepped from $-100 \mathrm{mV}$ to $+10 \mathrm{mV}$ while the cell was superfused with a medium containing calcium. After the capac. itative transient, the current became inward and slowly decayed with
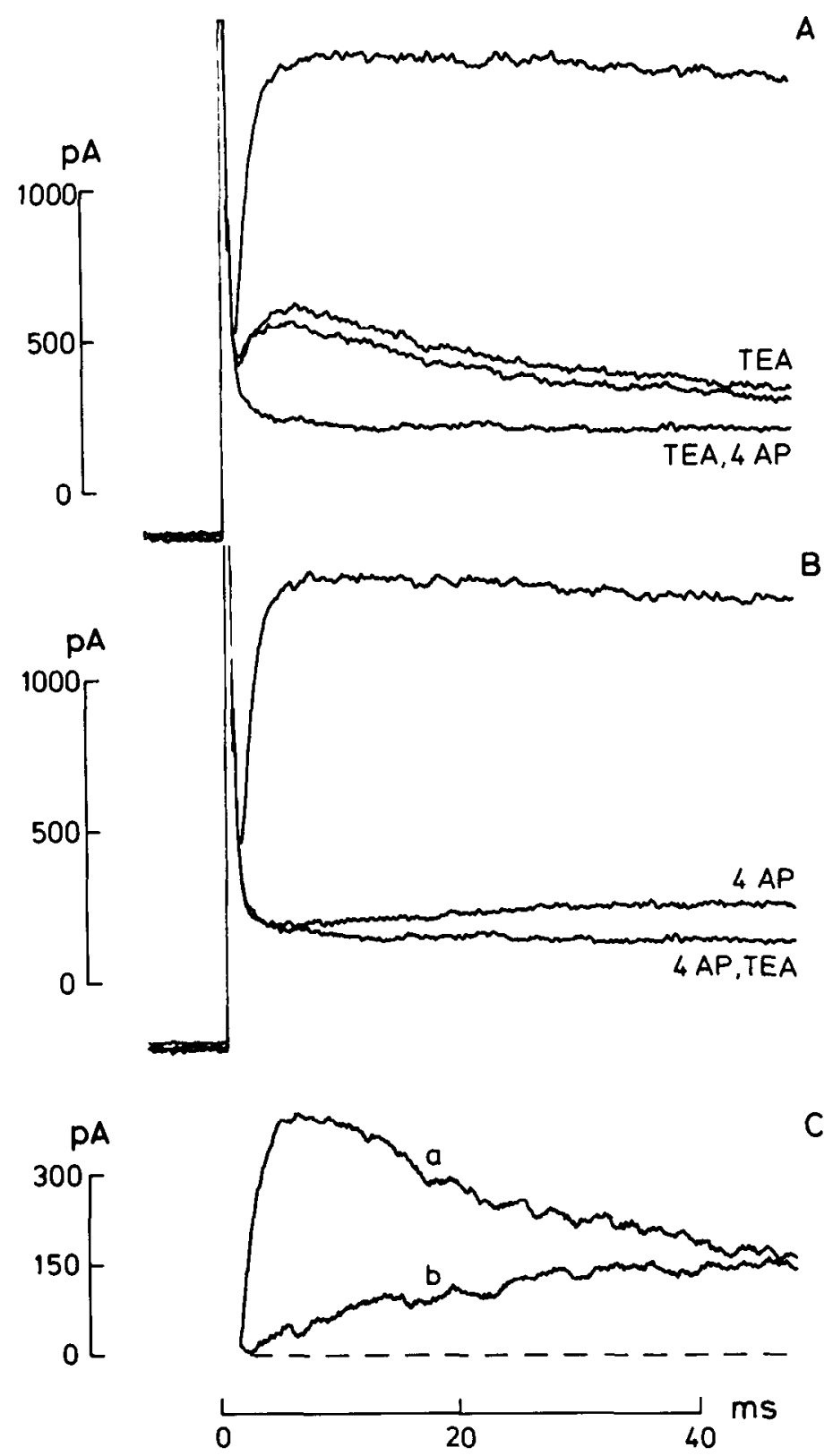

Figure 8. Possible existence of two potassium currents from a neuron in culture for 19 days. Superfusion solution and solution in the patch pipette were the same as those described in Figure 6. A, The cell was held in voltage clamp at $-100 \mathrm{mV}$ and stepped to $+30 \mathrm{mV}$. The current trace recorded in the control medium (with TTX) is at the top. A solution containing $20 \mathrm{~mm}$ TEA was then superfused and the second current trace from the top was recorded during the same voltage step (trace labeled TEA). The same protocol was again applied while superfusing with a solution containing 40 mM TEA (third trace from the top). Finally, a medium containing TEA (20 mM) and 4-AP (4 mM) was superfused (trace labeled TEA,4 AP). B, After the block with TEA and 4-AP, the cell was allowed to recover in the control medium (with $T T X$ ) and the current at the top was recorded in response to the voltage step to $+30 \mathrm{mV}$. A solution containing 4-AP $(4 \mathrm{~mm})$ was then superfused and the current was recorded again (trace labeled $4 A P$ ). The current recorded in the presence of TEA and 4-AP (trace labeled 4 AP,TEA) was also superimposed. $C$. The current recorded in the full block in $A$ was subtracted from the current recorded in the presence of TEA $(20 \mathrm{~mm})$. The difference is the current trace $a$ and represents the current blocked when 4 AP is added after TEA. The current trace $b$ is the difference in current between the full block in $B$ and the trace labeled 4-AP. The current $b$ represents the current blocked when TEA is added after 4-AP. 

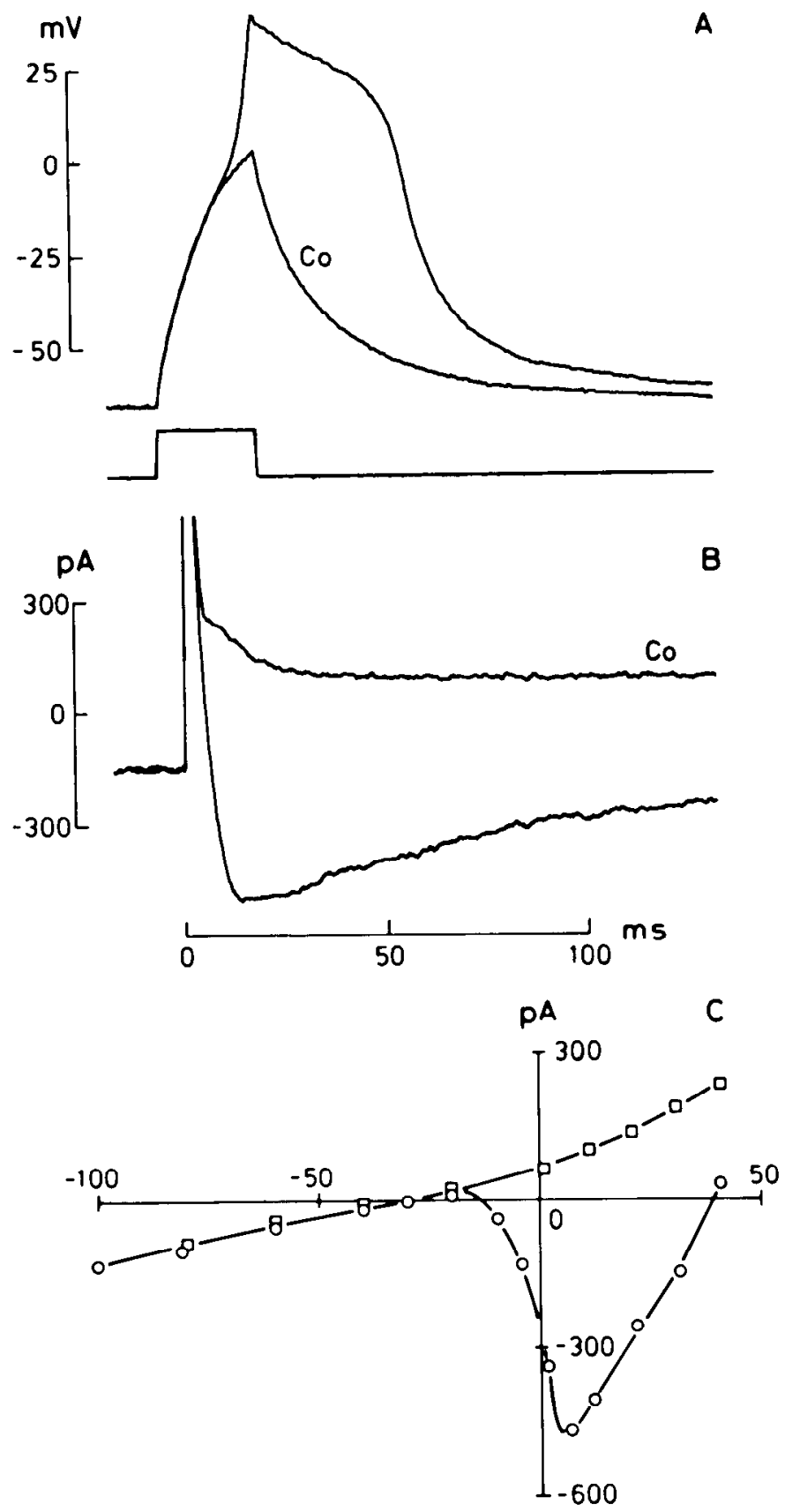

Figure 9. Presence of a voltage-dependent calcium current. All data are from the same neuron in culture for 29 days. The superfusion solution contained TTX $(5 \mu \mathrm{M})$, TEA $(20 \mathrm{~mm})$, and 4-AP $(4 \mathrm{~mm})$. The solution inside the pipette was the same as that described in Figure 5. A, Current clamp recording. The resting membrane potential was $-26 \mathrm{mV}$. The cell was held at $-66 \mathrm{mV}$ by injecting a constant hyperpolarizing current. A rectangular pulse of depolarizing current (135 pA) was applied for $50 \mathrm{msec}$ (bottom trace). This caused a depolarization of the membrane potential which triggered an action potential. The superfusion solution was then changed for one containing cobalt $(3 \mathrm{~mm})$ instead of calcium. Cobalt suppressed the action potential (trace labeled $\mathrm{Co}$ ). The effect of cobalt was totally reversible. The total duration of the traces is $300 \mathrm{msec}$. $B$, Voltage clamp recording The cell was held at $-100 \mathrm{mV}$ and stepped to $+7 \mathrm{mV}$, first in the presence of calcium and then in the presence of $3 \mathrm{~mm}$ cobalt (trace labeled Co) Cobalt suppresses an inward current. $C$, Current-voltage curves in the presence of calcium or cobalt. At each voltage step, the minimal current was measured and plotted as the circles (calcium) or as the squares (cobalt) Lines were drawn by eye. time. The same step of voltage was then repeated in the presence of extracellular cobalt (Fig. 9B, Co); clearly cobalt blocks an inward current. The difference between the current traces recorded in calcium and in cobalt decreases with time. This could either reflect the closure of calcium channels or the superposition of an outward current activated, for example, by an increase in the intracellular calcium concentration (possibly a calcium-activated potassium current).

In Figure $9 \mathrm{C}$ current-voltage curves obtained in the presence of calcium or cobalt are plotted (same cell as in Fig. 9, $A$ and $B$ ). Minimal current values during a voltage step were plotted as a function of the voltage. The circles show the results obtained in the presence of calcium and the squares show those in the presence of cobalt. Over the voltage range from -100 to $-20 \mathrm{mV}$ both curves are superimposed and are straight lines with a slope of $1.78 \mathrm{nS}$. In the presence of extracellular calcium, an inward current appears between -20 and $-10 \mathrm{mV}$. The calcium current goes through a maximum and tends toward an apparent reversal potential at +56 $\mathrm{mV}$ (measured by extrapolating the two curves in Fig. 9C). The calcium current illustrated in this figure is the largest that we observed. In eight cells the peak amplitude of the calcium current was $265 \pm 160 \mathrm{pA}$ (mean \pm SD). A common feature, however, was that the threshold for the calcium current was more depolarized than $-20 \mathrm{mV}(-17 \pm 4 \mathrm{mV})$.

\section{Discussion}

Neuronal cell growth. The experiments described in this paper have been done using spinal cord cells from 8- to 9-week-old human embryonic tissue obtained from aspiration abortions. Neurons from spinal cords of embryonic material younger than 8 weeks old also grew in culture, but there was not enough material to do a biochemical experiment. If the spinal cords were taken from fetuses older than 9 weeks, there were fewer neurons, much more cellular debris, and less synthesis of $\left[{ }^{3} \mathrm{H}\right] \mathrm{ACh}$. Therefore, there appears to be an optimal period for neuronal growth and more specifically for the survival of the cholinergic neurons.

We are interested in analyzing the effects of serum from patients with MND on these cultures (Touzeau and Kato, 1983). It was therefore encouraging to find that the neurons survive for several weeks in the presence of a standard tissue culture medium that contains human serum as the only undefined agent. Human serum can act as a source of neurotrophic factor(s) for these cells since they do not survive in the absence of serum. Human serum has also been shown to contain neurotrophic factors for rat spinal cord neurons (Kaufman and Barrett, 1983) and for chick ciliary ganglion neurons (Kato and Rey, 1982).

We have been unable to find conditions that would allow us to selectively eliminate the non-neuronal cells in the cultures without affecting neuronal properties. araC and FUdR were very effective in decreasing the number of non-neuronal cells and they had no effect on neuronal survival. However, the neurons that we considered as "healthy" using morphological and electrophysiological criteria had greatly reduced CAT and GAD activities and, in the case of araC, a decrease in the capacity to synthesize $\left[{ }^{3} \mathrm{H}\right] \mathrm{ACh}$. These results suggest that the non-neuronal cells are not necessary for the neuronal survival but they are required for the expression of the neurotransmitter phenotype. Under these conditions of antimitotic treatment, the human serum appears to supply the necessary neurotrophic factors required for neuronal survival.

Cellular characteristics. In our cultures of human spinal cord, tetanus toxin was found to bind primarily to cells that were classified as neuron-like with phase contrast optics. In addition, all of the neuron-like cells are labeled in the presence of a monoclonal antibody to neurofilament protein.

Other groups have examined the morphological properties of dissociated cells from human spinal cord. Kennedy et al. (1980) reported that cultures prepared with embryonic tissue from the 15th to the 21 st week contained astrocytes, oligodendrocytes, fibroblasts, 
and macrophages but none of the cells were positive for tetanus toxin binding. Using the same age of embryonic human spinal cord, Dickson et al. (1984) found that less than $2 \%$ of the cells in culture bound an antibody for neurofilament protein but 60 to $80 \%$ of the cells bound an antibody to GFAP. These authors state that the spinal cord neurons are probably sensitive to anoxia and consequently do not survive. We found that the age of the embryonic tissue was critical since few neurons from fetuses older than 9 weeks survived in culture; after 11 weeks of age, we could not identify any neuronal cells.

Neurotransmitter properties. In 1- to 2-week-old spinal cord cultures prepared from embryos 8 to 9 weeks old, the levels of CAT activity were similar to those found in spinal cord cultures of chick (Berg and Fischbach, 1978) and rat embryos (Smith and Appel, 1983). Also, the levels of synthesis and storage of $\left[{ }^{3} \mathrm{H}\right] \mathrm{ACh}$ agree with those found in rat spinal cord cultures (Smith and Appel, 1983; Giess and Wobcr, 1984) but are lower than those reported for chick spinal cord cultures (Berg, 1978).

The synthesis of $\left[{ }^{3} \mathrm{H}\right] \mathrm{ACh}$ was compared in cultures prepared from the anterior and posterior part of the spinal cord from 8-weekold embryonic tissue. After 2 weeks in culture, there was more ACh synthesized in the anterior part, which would indicate that cholinergic neurons had already migrated into the ventral horn and begun their biochemical differentiation. At present, it is not possible to state whether these are motoneurons or preganglionic cholinergic neurons. Malinsky and Malinska (1970) have studied the development of the human spinal cord and shown that at the eighth embryonic week, large immature motoneurons were present in the basal lamina. In addition, studies by Windle and Fitzgerald (1937) have suggested that the reflex arc in human spinal cord is completed during the eighth week in utero. Therefore, it is possible that the observed increase in ACh synthesis is due to an enrichment of the cholinergic motoneurons prepared from the anterior part of the cord.

Cultured neurons obtained from embryonic tissue usually show some degree of development in culture. In particular, spinal cord cells from chick embryos showed an increase in their ability to synthesize and store $\left[{ }^{3} \mathrm{H}\right] \mathrm{ACh}$ (Berg, 1978). We found that in the cultures of human spinal cord, the total CAT activity and ACh synthesis increased with time in culture whereas the total number of neurons remained constant. These results, however, might also be explained if the culture conditions induced primarily noncholinergic neurons to become cholinergic

It has been well established that GABAergic neurons exist in the spinal cord of both embryonic and adult tissue. In the cultures of human spinal cord, we find that there is an uptake system for $\left[{ }^{3} \mathrm{H}\right]$ GABA which takes place in both neurons and nonneuronal cells as determined by the use of specific inhibitors of GABA uptake. In addition, examination of autoradiographs of $\left[{ }^{3} \mathrm{H}\right] \mathrm{GABA}$ uptake suggest that approximately $60 \%$ of the neurons are labeled by $\left[{ }^{3} \mathrm{H}\right]$ GABA. These results agree with those reported by $\Gamma$ arb et al. (1979) for dissociated cultures of chick spinal cord.

Electrophysiological properties. Human spinal cord neurons obtained from 8- to 9-week-old embryonic tissue have many of the membrane properties expected from mature neurons. They have sodium, potassium, and calcium currents and can fire action potentials. In that sense, human spinal cord neurons in dissociated culture can be considered as apparently healthy.

The potassium current in human spinal cord neurons was found to be sensitive to two potassium-blocking agents, 4-AP and TEA. The results are consistent with the existence of two potassium currents, one with fast activation kinetics and the other with slow activation kinetics. These currents would be similar to those originally described as $I_{A}$ and $I_{K}$ in invertebrate neurons (Connor and Stevens, 1971a, b; Thompson, 1977). In human neurons both putative potassium currents can be totally inactivated by depolarized voltages, as has been found in invertebrate preparations (Connor and Stevens, 1971a, b).

Comparison of the electrophysiological properties with other preparations. The first report of electrophysiological recordings from human spinal cord in culture was that of Peterson et al. (1965). Explants from a 6-week-old embryo maintained in culture for several months had complex electrical responses after stimulation of the dorsal roots. Intracellular recording in spinal cord explants from older fetuses (17 weeks) suggested that neurons had resting potentials near $\mathbf{- 4 5} \mathrm{mV}$ (Hösli et al., 1973) and were sensitive to extracellularly applied glutamate and aspartate (Hösli et al., 1976). Intracellular recording in cultures of dissociated human dorsal root ganglion (DRG) neurons has been performed (Scott et al., 1979). This study demonstrated that human DRG neurons fired short duration action potentials. However, the emphasis of the study was not on the underlying ionic currents but rather on the passive electrical characteristics. In this respect human DRG neurons in culture differ from human spinal cord neurons. The main differences were the resting potential (more hyperpolarized in DRG) and the input resistance (10 to 15 times smaller in DRG). Part of the difference in resistance may be due to the larger size of the DRG neurons. There may also be developmental differences between the two systems, since the DRGs were obtained from older fetuses. Additional membrane channels might explain both the difterence in membrane resistance and that in the resting potential.

The electrophysiological properties of dissociated cultures of spinal cord from other species have been examined by several groups (Fischbach and Dichter, 1974; Spitzer and Lamborghini, 1976; Ransom et al., 1977; Nelson et al., 1981). A common feature of the spinal cord neurons in the various species, including human neurons, is that their action potential is largely, if not exclusively, sodium dependent. It appears that in most species where this was studied, the contribution of a calcium current to the action potential was small, at least once the neurons had reached an advanced state of their development (Fischbach and Dichter, 1974; Barrett and Barrett, 1976; Alvarez-Leefmans and Miledi, 1980; Heyer and MacDonald, 1982; Rogawski and Barker, 1983).

With respect to the potassium current in spinal cord neurons, current clamp studies revealed current-voltage curves corisistent with the existence of a potassium current in the chick (Fischbach and Dichter, 1974), in the mouse (Ransom et al., 1977), and in the frog (Barrett and Barrett, 1976). Similar currents were found in a voltage clamp study in cat motoneurons (Barrett et al., 1980). More recently it was reported that mouse spinal cord neurons in culture have three distinct potassium currents, $\left.\right|_{A}, l_{K}$ (Segal et al., 1984), and a calcium-activated potassium current (Rogawski and Barker, 1983).

The biochemical and electrophysiological properties of human spinal cord neurons in culture indicate that these neurons are similar to those from other species. This is relevant for two reasons. First, the cultured human neurons, as studied here, appear relatively mature and healthy and may therefore be a suitable tool for investigating disorders affecting the human nervous system. Second, the similarity observed here constitutes a justification to pursue studies in systems that are more easily accessible for ethical and technical reasons than the human material.

\section{References}

Albrechtsen, M., A. C. Von Gerstenberg, and E. Bock (1984) Mouse monoclonal antibodies reacting with human brain glial fibrillary acidic protein. $\mathrm{J}$. Neurochem. 42: 86-93.

Alvarez-Leefmans, F. J., and R. Miledi (1980) Voltage sensitive calcium entry in frog motoneurones. J. Physiol (Lond.) 308: 241-257.

Anderton, B. H., D. Breinburg, M. J. Downes, P. J. Green, B. E. Tomlinson, J. Ulrich, J. N. Wood, and J. Kahn (1982) Monoclonal antibodies show that nourofibrillary tangles and neurofilaments share antigenic determinants. Nature 298: $84-86$

Bader, C. R., and D. Bertrand (1984) Effect of changes in intra- and exlracellular sodium on the inward (anomalous) rectification in salamander photoreceptors. J. Physiol. (Lond.) 347: 611-631.

Bader, C. R., D. Bertrand, E. Dupin, and A. C. Kato (1983) Development of electrical membrane properties in cultured avian neural crest. Nature 305: 808-810

Barrett, E. F., and J. N. Barrett (1976) Separation of two voltage-sensitive potassium currents, and demonstration of a tetrodotoxin resistant calcium current in frog motoneurones. J. Physiol. (Lond.) 255: 737-774. 
Barrett, E. F., J. N. Barrett, and W. E. Crill (1980) Voltage-sensitive outward currents in cat motoneurones. J. Physiol. (Lond.) 304: 251-276.

Berg, D. K., and G. D. Fischbach (1978) Enrichment of spinal cord cell cultures with motoneurons. J. Cell Biol. 77: 83-98.

Bornstein, M. B. (1958) Reconstituted rat-tail collagen used as a substrate for tissue cultures on coverslips in Maximow Slides and roller tubes. Lab. Invest. 7: 134-137.

Bottenstein, J. E., and G. H. Sato (1979) Growth of a rat neuroblastoma cell line in serum-free supplemented medium. Proc. Natl. Acad. Sci. U. S. A. 76: 514-517.

Bowery, N. G., G. P. Jones, and M. J. Neal (1976) Selective inhibition of neuronal GABA uptake by cis-1,3-aminocyclohexane carboxylic acid. $\mathrm{Na}$ ture 264: 281-284.

Brazeau, P., N. Ling, $\vdash$. tsch, P. Bohlen, R. Benoit, and R. Guillemin (1981) High biological activity of the synthetic replicates of somatostatin-28 and somatostatin-25. Regul. Pept. 1: 255-264.

Chalazonitis, A., and G. D. Fischbach (1980) Elevated potassium induces morphological differentiation of dorsal root ganglionic neurons in dissociated cell culture. Dev. Biol. 78: 173-183

Connor, J. A., and C. F. Stevens (1971a) Inward and delayed outward membrane currents in isolated neural somata under voltage clamp. J. Physiol. (Lond.) 213: 1-19.

Connor, J. A. and C. F. Stevens (1971b) Voltage-clamp studies of a transient outward membrane current in gastropod neural somata. J. Physiol. (Lond.) 213: $21-30$.

Currie, D. N., and G. R. Dutton (1980) $\left({ }^{3} \mathrm{H}\right)$-GABA uptake as a marker for cell type in primary cultures of cerebellum and olfactory bulb. Brain Res. 199: 473-481.

Dickson, J. G., T. P. Flanigan, and F. S. Walsh (1984) Antigen expression in human neuronal primary cell cultures and human $\times$ mouse neuronal cell hybrids. In Research Progress in Motor Neurone Disease, F. C. Rose, ed., pp. 388-404, Pitman Press, Bath.

Farb, D. H., D. K. Berg, and G. D. Fischbach (1979) Uptake and release of $\left({ }^{3} H\right)-\gamma$-aminobutyric acid by embryonic spinal cord neurons in dissociated cell culture. J. Cell Biol. 80: 651-661.

Fenwick, E. M. A. Marty, and E. Neher (1982) A patch-clamp study of bovine chromaffin cells and of their sensitivity to acetylcholine. J. Physiol. (Lond.) 331: 577-597.

Fischbach, G. D., and M. A. Dichter (1974) Electrophysiologic and morphologic properties of neurons in dissociated chick spinal cord cell cultures. Dev. Biol. 37: 100-116.

Fonnum, F. (1975) A rapid radiochemical method for the determination of choline acetyltransferase. J. Neurochem. 24: 407-409.

Giess, M. -C., and M. Weber (1984) Acetylcholine metabolism in rat spinal cord cultures: Regulation by a factor involved in the determination of the neurotransmitter phenotype of sympathetic neurons. J. Neurosci. 4: 14421452

Hamill, O. P., A. Marty, E. Neher, B. Sakmann, and F. J. Sigworth (1981) Improved patch clamp techniques for high resolution current recording from cells and cell-free membrane patches. Pflugers Arch. 391: 85-100.

Heyer, E. J., and R. L. MacDonald (1982) Calcium- and sodium-dependent action potentials of mouse spinal cord and dorsal root ganglion neurons in cell culture. J. Neurophysiol. 47: 641-655.

Hildebrand, J. G., D. L. Barker, E. Herbert, and E. A. Kravitz (1971) Screening for neurotransmitters: A rapid radio-chemical procedure. J. Neurobiol. 2 : 231-246.

Hodgkin, A. L., and A. F. Huxley (1952) The dual effect of membrane potential on sodium conductance in the giant axon of Loligo. J. Physiol. (Lond.) 116: 497-506.

Hösli, L., E. Hösli, and P. F. Andres (1973) Light microscopic and electrophysiological studies of cultured human central nervous system. Eur. Neurol. 9: 121-130.

Hösli, L., E. Hösli, and P. F. Andres (1974) Electrophysiological and histochemical properties of fetal human spinal cord in tissue culture. In Dynamics of Degeneration and Growth of Neurons, K. Fuxe, L. Olson, and Y. Zotterman, eds., pp. 521-532, Pergamon Press, Oxford.

Hösli, L., P. F. Andres, and E. Hösli (1976) lonic mcchanisms associated with the depolarization by glutamate and aspartate on human and rat spinal neurones in tissue culture. Pflugers Arch 363: 43-48.
Karnovsky, M. J., and L. Roots (1964) A "direct-colouring" thiocholine method for cholinesterases. J. Histochem. Cytochem. 12: 219-222.

Kato, A. C., and M. J. Rey (1982) Chick ciliary ganglion in dissociated cell culture. I. Cholinergic properties. Dev. Biol. 94: 121-130.

Kaufman, L. M., and J. N. Barrett (1983) Serum factor supporting long-term survival of rat central neurons in culture. Science 220: 1394-1396.

Kelly, J. S., and F. Dick (1976) Differential labeling of glial cells and GABA inhibitory interneurons and nerve terminals following the microinjection of ${ }^{3} \mathrm{H}-\beta$-alanine, ${ }^{3} \mathrm{H}$-DABA and ${ }^{3} \mathrm{H}$-GABA into single folia of the cerebellum. Cold Spring Harbor Symp. Quant. Biol. 40: 93-106.

Kennedy, P. G. E., R. P. Lisak, and M. C. Raff (1980) Cell type-specific markers for human glial and neuronal cells in culture. Lab Invest 43: 342351.

Kornberg, A. (1955) Lactate dehydrogenase of muscle. Methods Enzymol. 1: $441-443$.

Lasher, R.S., and I. S. Zagon (1972) The effect of potassium on neuronal differentiation in cultures of dissociated newborn rat cerebellum. Brain Res. 41: 482-488

Malinsky, J., and J. Malinska (1970) Developmental stages of the prenatal spinal cord in man. Fol. Morphol. Czech. Acad. 18: 228-235.

Mirsky, R., L. M. B. Wendon, P. Black, C. Stolkin, and D. Bray (1978) Tetanus toxin: A cell surface marker for ncurones in culture. Brain Res. 148: 251259.

Moore, K. L. (1982) The embryonic period. In The Developing Human, K. L. Moore, ed., pp. 70-92, W. B. Saunders Co., Philadelphia.

Nelson, P. G., E. A. Neale, and R. L. MacDonald (1981) Electrophysiological and structural studies of neurons in dissociated cell cultures of the central nervous system. In Excitable Cells in Tissue Culture, P. G. Nelson and M. Lieberman, eds., pp. 39-80, Plenum Press, New York.

O'Lague, P. H., D. D. Potter, and E. J. Furshpan (1978) Studies on rat sympathetic neurons developing in cell culture. I. Growth characteristics and electrophysiological properties. Dev. Biol. 67: 384-403.

Peterson, E. R., S. M. Crain, and M. R. Murray (1965) Differentiation and prolonged maintenance of bioelectrically active spinal cord cultures (rat, chick and human). Z. Zellforsch. 66: 130-154

Prochiantz, A., A. Delacourte, M. C. Daguet, and D. Paulin (1982) Intermediate filament proteins in mouse brain cells cultured in the presence or absence of fetal calf serum. Exp. Cell Res. 139: 404-410.

Ransom, B. R., E. Neale, M. Henkart, P. N. Bullock, and P. G. Nelson (1977) Mouse spinal cord in cell culture. I. Morphology and intrinsic neuronal electrophysiologic properties. J. Neurophysiol. 40: 1132-1150.

Rogawski, B. R., and J. L. Barker (1983) Effects of 4-aminopyridine on calcium action potentials and calcium current under voltage clamp in spinal neurons. Brain Res. 280: 180-185.

Scott, B. S., T. L. Petit, L. E. Becker, and B. A. V. Edwards (1979) Electric membrane properties of human DRG neurons in cell culture and the effect of high $\mathrm{K}$ medium. Brain Res. 178: 529-544.

Segal, M., M. A. Rogawski, and J. L. Barker (1984) A transient potassium conductance regulates excitability of cultured hippocampal and spinal neurons. J. Neurosci. 4: 604-609.

Smith, R. G., and S. H. Appel (1983) Extracts of skeletal muscle increase neurite outgrowth and cholinergic activity of fetal rat spinal motor neurons. Science 219: 1079-1081.

Spitzer, N. C., and J. E. Lamborghini (1976) The development of the action potential mechanism of amphibian neurons isolated in culture. Proc. Natl. Acad. Sci. U. S. A. 73: 1641-1645.

Streeter, G. L. (1920) Weight, sitting height, head size, foot length and menstrual age of the human embryo. Contrib. Embryol. 11: 143-170.

Thompson, S. H. (1977) Three pharmacologically distinct potassium channels in molluscan neurones. J. Physiol. (Lond.) 265: 465-488.

Touzeau, G., and A. C. Kato (1983) Effects of amyotrophic lateral sclerosis sera on cultured cholinergic neurons. Neurology 33: 317-322.

Tucek, S. (1982) The synthesis of acetylcholine in skeletal muscles of the rat. J. Physiol. (Lond.) 322: 53-69.

Weber, M. J., B. Raynaud, and C. Delteil (1985) Molecular properties of a cholinergic differentiation factor from muscle-conditioned medium. J. Neurochem., in press.

Windle, W. F., and J. E. Fitzgerald (1937) Development of the spinal reflex mechanism in human embryos. J. Comp. Neurol. 67: 493-509. 